\title{
Érdem és protokoll. Államfői kitüntetések a Rippl-Rónai Múzeumban
}

\author{
VARGA ÉVA \\ Rippl-Rónai Megyei Hatókörű Városi Múzeum, H-7400 Kaposvár, Fő u. 10., e-mail: varga@smmi.hu
}

\begin{abstract}
VARGA, É.: Merit and Protocol. Head of States' Medals in the Rippl-Rónai Museum.

Abstract: The study presents the career of Pál Losonczi, a former head of state of Hungary (1967-1987) through his honors, which are held in the Rippl-Rónai Museum. Through the example of an award, the author also shows how the honors are processed.
\end{abstract}

Keywords: international relations, Losonczi Pál, Kádár era, phaleristics, Hungary

\section{Bevezetés}

„Nagyon nem szerette a protokollt, és az Isten azzal verte meg, hogy a protokoll lett a munkaköre" - mondta Losonczi Pálról Kapossi Kiss István, az Elnöki Tanács elnökének volt sajtótitkára és beszédírója. Azaz, véleménye szerint (és ezt sokan osztották), egyszerü, gyakorlati ember volt Losonczi Pál, utálta a diplomáciai formalitásokat, ennek ellenére húsz éven át - mondhatni - szinte mással sem foglalkozott. A sors iróniája, hogy hagyatékával, mint Magyarország utazó államfője, pályája során kapott kitüntetéseivel hagyott maradandó nyomot maga után.

Ha lehetőségem nyílt volna rá, sok mindenről kérdeztem volna a néhai elnököt. Leginkább persze arról, hogy minek köszönhette mesébe illö karrierjét, azaz hogyan lett egy Isten háta mögötti somogyi kisközségben élő földműves nagyobbik fiából - kvázi - „király”? Aztán a többi kérdést is feltettem volna, azokat is, amit a Népszabadság újságírója szándékozott: miként élte meg a rendszerváltást, hogyan érintette a magyar mezőgazdaság megváltozott helyzete, a tsz-ek széthullása. Arról is faggattam volna, érezte-e, hogy a korabeli pártvezetés tulajdonképpen kirakatembernek használta. ${ }^{1}$ Vajon szóba állt volna-e egy történész-muzeológussal, aki arra törekszik, hogy „sine ira et studio” felkutassa a történetét, azaz velem?

Nemhogy ilyen kérdéseket, de másmilyeneket sem tehetett fel neki senki. Losonczi Pál 1989-ben teljesen visszavonult. Barcsra költözött. A rendszerváltáskor kijelentette, hogy soha nem fog a sajtónak nyilatkozni, és ehhez 86 éves korában bekövetkező haláláig szigorúan tartotta is magát. Kerülte a nyilvánosságot. Vajon miért? Kényelemből? Sértett önérzetből? Büszkeségből? Találgatunk... A rendszerváltás fényében joggal tartott az értetlenségtől. Sőt...! Elzárkózásával ugyanakkor - úgy vélem - kifejezésre juttatta azt is,

1 Pogonyi Lajos: Elhunyt Losonczi Pál.= Népszabadság. 2005. március 30 hisz abban, amit egykor emelt fővel képviselt. Betöltött pozíciójához, tegyük hozzá, méltatlan (egyúttal felesleges és hiábavaló) is lett volna a magyarázkodás. Mindenesetre az aktuálpolitika mentén született (sokszor szenzációhajhász) viszonyulás szélsőséges megítélést eredményezett (Id. például a halálhírének apropóján keletkezett sajtót), megnehezítve ezzel szakmánk dolgát.

2006-ban, egy évvel az elnök halála után - úgy tűnik - személye mélyebben felkeltette a történészek érdeklődését. ${ }^{2}$ 2012-ben nevét a napi sajtó újra felkapta - szinte már-már megdicsőült színezettel - az év elején zajló államfői mizéria kapcsán. Ezúttal a Somogy megyei múzeumba került kitüntetései apropóján szólunk róla, árnyalva a bontakozó képet: ki volt Losonczi Pál.

\section{A gyűjtemény és sorsa}

A bevezető gondolatokból, úgy vélem, egyértelművé vált az olvasó előtt, hogy a címben szereplő államfői kitüntetések a Losonczi Pál nevével fémjelzett gyűjteményt rejtik. Már önmagában az anyag múzeumba kerülésének sajátos története van. Ez a história ugyancsak Losonczi Pál, illetve a Kádár-kor aktuálpolitikai megítélésével függ össze. ${ }^{3}$

1987-ben (68 éves korában) Losonczi Pál nyugdíjazását kérte. Ekkor már éppen húsz éve volt államfő. A Kádár-korszak legmagasabb rangú közjogi méltósága volt, közélettől való visszavonulását rangjához méltón tervezte meg. Csakhamar - még ebben az évben - Budapestről nagy rendőri biztosítással, titokban a Magyar Nemzeti Bank kaposvári fiókjának trezorjába kerültek kincsei, közszereplőként kapott ajándéktárgyai, kitüntetései, amelyeket rövidesen (1988-ban) a Somogy megyei múzeum kiállításán tártak a nagyközönség elé. Jóllehet akkor a tárgyak szakszerü meg-

2 A Losonczi-gyűjtemény feldolgozásához az alábbi tanulmányokban számos hasznos információt találtunk. Komiszár Dénes: Mezőgazdaság és protokoll. Losonczi Pál kitüntetései a sajtó tükrében.= Somogyi Múzeumok Közleményei. Szerk.: Winkler Ferenc. Kaposvár, 2007. 91-108. p.

Bolvári-Takács Gábor: Eszme és föld. Vázlatpontok Losonczi Pál agrárpolitikusi portréjához.= Zempléni Múzsa. 2006. 2. sz. 11-24. p. Bolvári-Takács Gábor: Csendben a csúcson. Vázlatpontok Losonczi Pál államfői portréjához. Zempléni Múzsa. VIII. évfolyam 3. (31.) szám - 2008. ősz, 13-27. p. (Megj.: Az államfői kitüntetésekről a szerzőnek fals információi vannak.)

3 A szocializmus időszaka is történelmünk része. A történészként valljuk, hogy a feldolgozó tevékenység csak akkor lehet eredményes, sikeres, ha a korhoz elfogulatlanul, sine ira et studio viszonyulnak a szakemberek. 


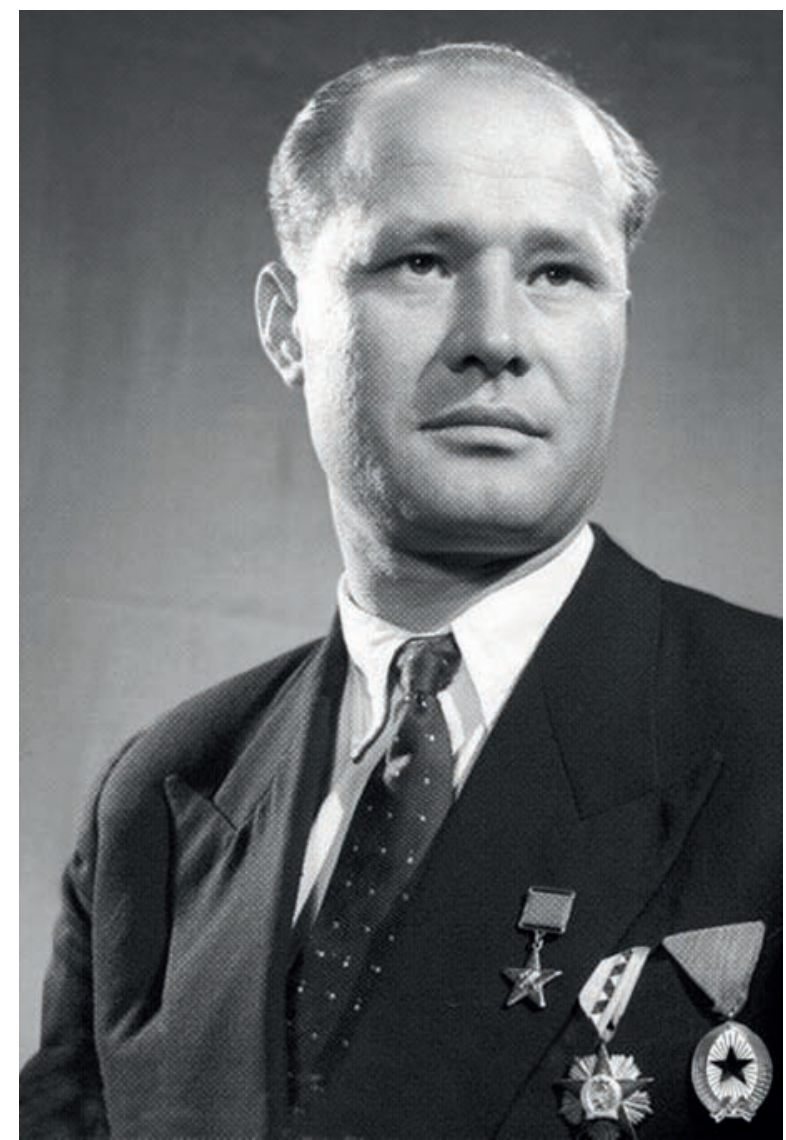

Losonczi Pál portréja, 1956. A „sikeres tsz-elnök” az 1953-ban kapott Munka Érdemrendet, az 1954-ben kapott Szocialista Munka Hőse kitüntetést és a vele járó Magyar Népköztársaság Érdemrendjét viseli. Fotó: MTI (Járai Rudolf).

határozása elmaradt ${ }^{4}$, elmondható, hogy ezt a kiállítást az akkori tudásnak, érdeklődésnek megfelelően hozták létre. ${ }^{5}$

A kiállítás több szempontból is rendkívülinek számított. Köztudomású, hogy az államfői kitüntetések a falerisztika legszebb darabjai. Losonczi Pál kitüntetésanyaga az idő tájt nagyságrendben a legnagyobb volt az 1918 utáni magyar államfői kitüntetések sorában. ${ }^{6}$

4 Sajnos, a tárgyfeliratok csekély falerisztikai hozzáértésről tanúskodtak. (A NET titkárságán nem voltak kitüntetés-szakértők.) Ugyanez a megállapítás vonatkozik a Magyar Közlönyben, a viselési engedélyekben szereplő elnevezésekre is.

5 H. B.: Közkincs az államfői ajándék. Kiállítás Losonczi Pál kitüntetéseiből. Somogyi Néplap. 1988. október 29. 5. p.

6 Mint ismeretes, Horthy kitüntetései a család elhurcolása idején megfogyatkoztak, 1994-ben pedig a kollekció töredéke került haza. (Erről Id. Makai Ágnes: Hőstettek és protokoll. Horthy Miklós kitüntetései. Rubicon. 2001/1-2. 40-41. p.) Bár Losoncziéhoz fogható kitüntetései Kádárnak is voltak, de azokat a főtitkár halála után elárverezték egyéb más relikviáival egyetemben. Göncz Ár pád Nemzeti Múzeum Éremtárába került kitüntetései pedig talán kétszeresét is kiteszik a Losonczi-féle anyagnak. Ám nem szorul különösebb magyarázatra, hogy azok egy politikatörténeti szempontból más, újabb korszakot képviselnek. (Erről ld.: Héri Vera - Kőhegyi Mihály: Az észt Pro Terra Mariana érdemkereszt. = Az Érem. 2001./2. 51-52. p.)
A Losonczi-anyag a Kádár-kor történetének színes gyűjteménye, benne számos kuriózumnak számító afrikai, közel-keleti, latin-amerikai kitüntetéssel. ${ }^{7}$ A kiállítás egyedülálló volt a tekintetben is, hogy Magyarországon eladdig „nem volt rá példa, hogy fontos közszolgálat után az elismerésként kapott kitüntetések, érdemrendek, dísztárgyak a köz kincsévé váljanak." fogalmazott Horányi Barna, a helyi napilap újságírója. "Losonczi Pál gesztusa példa" - nyilatkozta a sajtónak Gyenesei István, aki akkor a Somogy Megyei Tanács elnöki pozícióját töltötte be.

A gondos rendezés 1988-ban több szempontot igyekezett figyelembe venni: 1. A helyén kezelte az ország rangban első emberének azt a gesztusértékü szándékát, hogy közszemlére bocsássa részben személyének, részben közszolgálati hivatalának köszönhető ereklyéit, amelyekről úgy gondolkodott, hogy azok - személyén keresztül - az országot illetik. A kaposvári kiállítás létrejöttével egyúttal megcsillant a remény, hogy a múzeumi letétbe helyezett kiállítási tárgyak Losonczi Pál adományaként - végleg Somogy megye múzeumába kerülnek majd. 2. Természetesen érvényesült az a rendezői szándék, hogy az Elnöki Tanács elnökének külföldi utazásai alkalmából kapott elismerésekkel a magyar diplomácia sikereit, irányának sokféleségét is bemutassák. 3. További rendezői szempont volt a tárgyak iparmüvészeti szépségének, esztétikumának, csilli-villi küllemének, meseszerű pompájának, nemes anyagában testet öltő materiális értékének reprezentatív érvényesítése.

Summa summárum: a kiállítás sikeres volt, vonzotta a látogatókat. Megérte, sőt, néhány évvel túl is élte a rendszerváltást.

Ez az időszak a kiállító intézmény, jogelődünk, a Somogy Megyei Múzeumok Igazgatósága életében többszöri igazgatóváltással párosult. Az épp 1991-ben regnáló régész múzeumigazgató súlyos vezetői és muzeológusi, szakmai hibát vétett, amikor a Losonczi-anyag rendszerváltást követő további bemutatása miatti felháborodásának a nyilvánosság előtt hangot adott. Rádiónyilatkozata felkavarta a kedélyeket. Az igazgató csakhamar távozott hivatalából, ${ }^{8}$ a kiállítást le kellett bontani, az anyagot vissza kellett adni a volt államfönek.

A kitüntetések a kiállítás bontásakor (a visszaszolgáltatás előtt) kerültek először történész-muzeológusok kezébe. Ekkor kerültek leltárba. Bár a mütárgyleírásokba sok, mára mosolyt fakasztó megnevezésbeli pongyolaság került (pl. a szomáliai kitüntetés jelvényében szereplő leopárdot - nemes egyszerüséggel - valami macskaféle vadállatnak tituláltuk), a tárgyak beazonosíthatóak lettek. Anyagi, azaz nemesfém értékének felbecsülését Rónai Attila, kaposvári ötvös mester végezte el. Nem volt könnyủ dolga, amint azt több nemesfém, drágakő aukciós oldalakon található, utólagos beazonosítása bizonyítja.

7 Igen, kuriózumok. Hiszen egyes országokkal már nem tartunk fönn olyan szintű kapcsolatot, mint azokban az időkben, illetve ezekben az országokban is változtak a rezsimek, s ezzel összefüggésben a kitüntetések is.

8 Jungbert Béla 3 hónapig volt múzeumigazgató Kaposváron. 


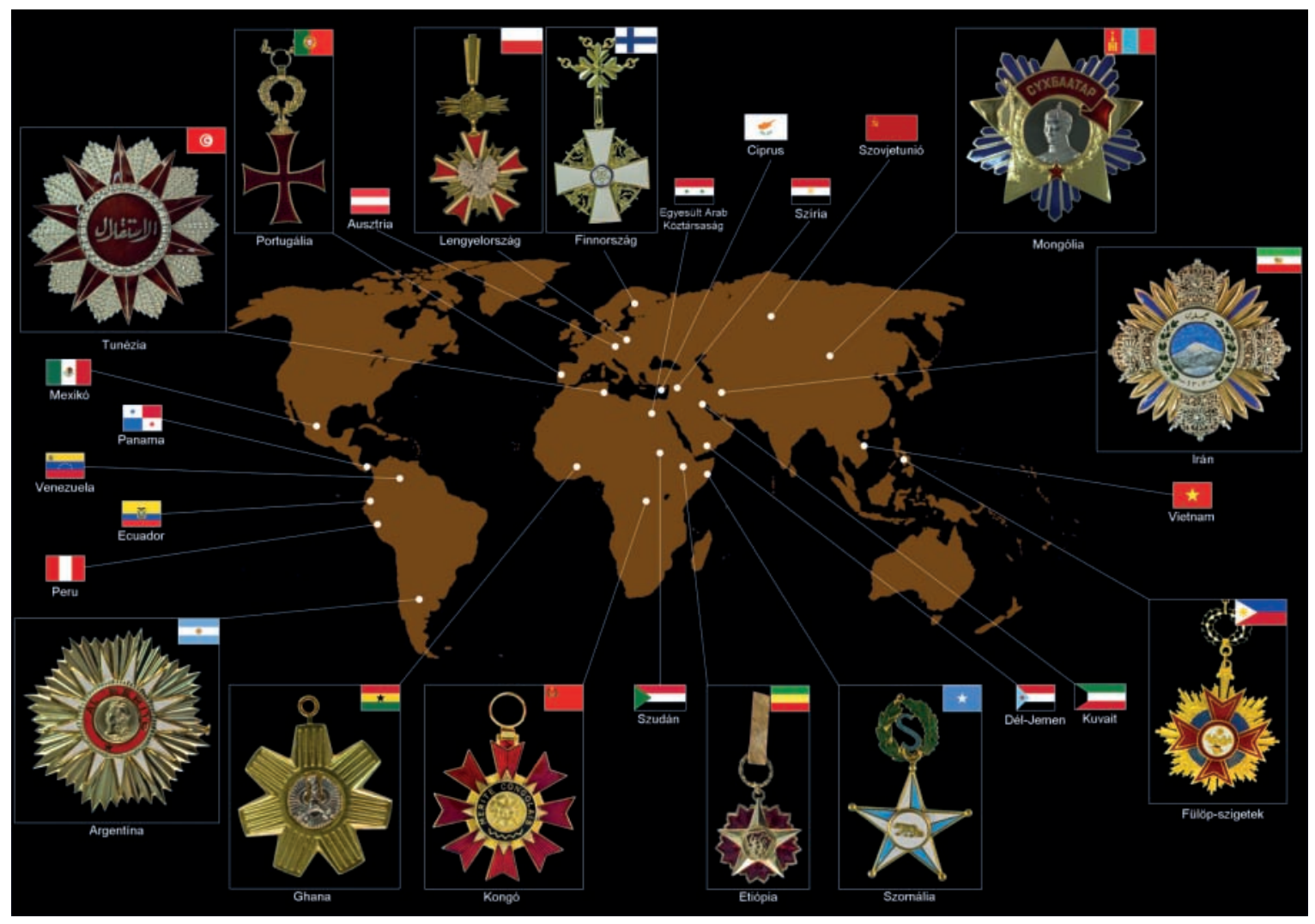

Losonczi Pál múzeumunkban őrzött államfői kitüntetései a térképen jelzett országokból származnak. A gyüjtemény feldolgozottságát a kitüntetést szimbolizáló képek (csillag, medál) jelzik.

(Az illusztrációt készítette: Gyurákovics Norbert)

A közgyűjteményben dolgozó szakemberek tudták, hogy a politikai kurzusok, társadalmi körülmények, értékrendszerek változásával a kitüntetések erkölcsi értéke minősül át, történelmi emlékként azonban továbbra is tanúskodnak korukról: adományozóik szándékáról, a kitüntetettek társadalmi szerepéről, alkotóik művészi teljesítményéről.

A bölcs gondolatok azonban nem tudták befolyásolni a történteket, Losonczi Pál a bemutatott anyagot visszakérte. Lábra kapott az a hír, miszerint a volt elnök jövedelme a felére csökkent ${ }^{9}$ és a somogyi önkormányzattól, a múzeum fenntartójától a kitüntetéseiért, ajándéktárgyaiért végkielégítést, illetve életjáradék folyósítását várta volna el. Ezt az önkormányzat azonban nem vállalta. A múzeumnak ezekről az elképzelésekről nem volt tudomása, nem tudott hatást gyakorolni az eseményekre. Mindenesetre a tárgyak tizenhárom évi lappangása vette kezdetét. Megszerzésükre múzeumok és magángyüjtők egyaránt aspiráltak, mígnem 2004-ben a Losonczi nevével fémjelzett gyűjtemény - azaz a kitüntetésanyag az ajándéktárgyak nélkül - visszakerült a Somogy megyei múzeumba. ${ }^{10}$

9 Az 1991. évi XII. törvény hatályon kívül helyezte azt az 1988as minisztertanácsi rendeletet, amely az általános szabályoktól eltéröen határozta meg az Elnöki Tanács elnökének, a miniszterelnöknek és az Országgyülés elnökének nyugdíját.

10 A kitüntetés-gyűjteményt értékének töredékéért megvásárolta Somogy Megye Önkormányzata a megyei múzeum gyüjteménye számára.
A gyűjteményből készült válogatással azóta több alkalommal találkozhatott a közönség: például 2009ben, a múzeum alapításának centenáriuma alkalmából készült, a gyűjtemények legszebb tárgyait bemutató kiállításán, avagy 2010-ben A tegnap világa címü újkortörténeti kiállításon, amelyet a történész-muzeológusok Kaposváron rendezett országos konferenciája alkalmából rendeztünk. Ez utóbbi kiállítás aztán 2011ben ,járta” a megyét. Bemutattuk Marcaliban és Nagyatádon is. A gyűjtemény több darabja e sorok írásakor, 2020-ban a Magyar Kereskedelmi és Vendéglátóipari Múzeum „Protokoll és diplomácia” című időszaki kiállításán szerepel.

\section{Pályavázlat a gyűjtemény tükrében}

A hazai kitüntetésekkel, amit Losonczi Pál kapott, nincs nehéz dolgunk. Rendelkezésre áll a szakirodalom. Leírható, bemutatható velük Losonczi Pál karrierjének első, vidéki korszaka, az az időszak, amikor felfigyel rá az országos politika.

\section{A sikeres tsz-elnök}

Losonczi 1939-ben (20 éves korában) csatlakozik az illegális kommunista párthoz. A világháború után nem meglepő, hogy utat talál az MKP-hez. Pártkarrierje gyorsan emelkedik és igazolja a választott párttisztsé- 
1991

$54 \%$

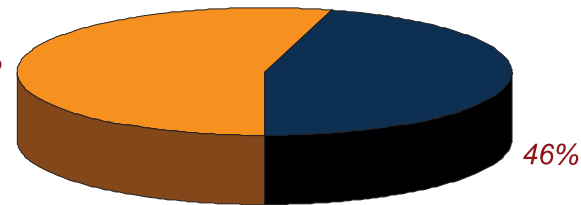

$\square$ Kitüntetések, érdem-és emlékérmek $\square$ Ajándéktárgyak

2004

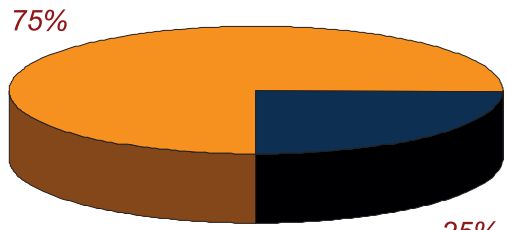

$25 \%$

$\square$ Kitüntetések, érdem- és emlékérmek $\square$ Ajándéktárgyak

A Losonczi-gyüjtemény összetétele.

(Az illusztrációt készítette: Gyurákovics Norbert)

geihez ${ }^{11}$ füződő reményeket. Élére áll a szövetkezeti mozgalomnak, és a barcsi Vörös Csillag Termelöszövetkezet elnöke lesz. ${ }^{12}$

A kollektivizálásban és a termelésben élen járó téesz a korabeli értékrend szerint nagy sikereket ér el. Sorra kapja az elismeréseket. ${ }^{13} \mathrm{Az}$ elnök tevékenységét pedig 1953-ban a Munka Érdemrend ${ }^{14}$, 1954-ben pedig a

11 1945-töl a Magyar Kommunista Párt községi titkára, 1946-ban a párt barcsi vezetőségének tagja. 1948-ban az MDP barcsi járási bizottságában, 1950-től pedig a megyei pártbizottságban találjuk.

12 Újabban felkapott hír (Id. szerte az interneten) az, hogy Losonczi Pál apja, a Vitézi Rend tagja volt és telket is kapott. Losonczi Mihályt 1923-ban avatták vitézzé. Egy magángyűjteményben őrzött 1943as bolhói képeslap tanúsága szerint a vitézi címet fia, Losonczi Pál használta is. Később, ifjúkorára való emlékezésében ennek - természetesen - nyomát nem találjuk. (Id. pl.: Losonczi Pál: „Örvendj hazám! Nézd mennyi jeles sereg!..."= Vallomások Somogyról. Szerk.: Paizs Gábor.Kiad.: MSZMP Somogy megyei Bizottsága, Kaposvár, 1970.) A tények feltárása még várat magára.

A háború után, a földosztáskor Losonczi birtokot szerez a Barcs határában fekvő Szilonicspusztán, ahova szülőfalujából, Bolhóból költözött több falubeli parasztcsaláddal együtt, mivel itt nagyobb földhöz juthattak a szegényparasztok és a nincstelenek. Losonczi visszaemlékezése szerint a pusztai élet egymásrautaltságából jutottak el 1948 októberében a földbérlő szövetkezeti formáig. majd néhány hónap múlva 10 család 77 hektár területen Losonczi vezetésével megalakított egy III. típusú termelőszövezkezeti csoportot. „Ezek voltak az 1950 tavaszán létrehozott Vörös Csillaghoz vezetett lépcső első fokai."- olvashatjuk Benke József: Egy magyar szocialista mezőgazdasági nagyüzem története. A barcsi Vörös Csillag 40 éve című monográfiájának Losonczi Pál írta elöszavában. (Barcs, 1987. 5. p.)

13 A barcsi téesz 1952-ben „az ország II. legjobb termelőszövetkezete”, „az ország legjobb burgonyatermelő szövetkezete”, ,az ország legjobb silózó szövetkezete” kitüntető címeket kapja. 1953-ban „az ország élenjáró szövetkezeti gazdasága” címet és pénzjutalmat. Az átadáson jelen lévő Dobi István elismerő szavai jelzik: országos figyelem fordul a mintagazdaság felé. (Benke József: Egy magyar szocialista mezőgazdasági nagyüzem története. A barcsi Vörös Csillag 40 éve. Barcs, 1987. 145. p., valamint 150-151. p.)

14 A kitüntetést 1953. április 4-én, „a felszabadulás 8. évfordulója alkalmából” adta át Dobi István. (Magyar Közlöny. 1953. április 4.; ill. Kitüntetések április 4. alkalmából.=Szabad Nép. 1953. április 4.)

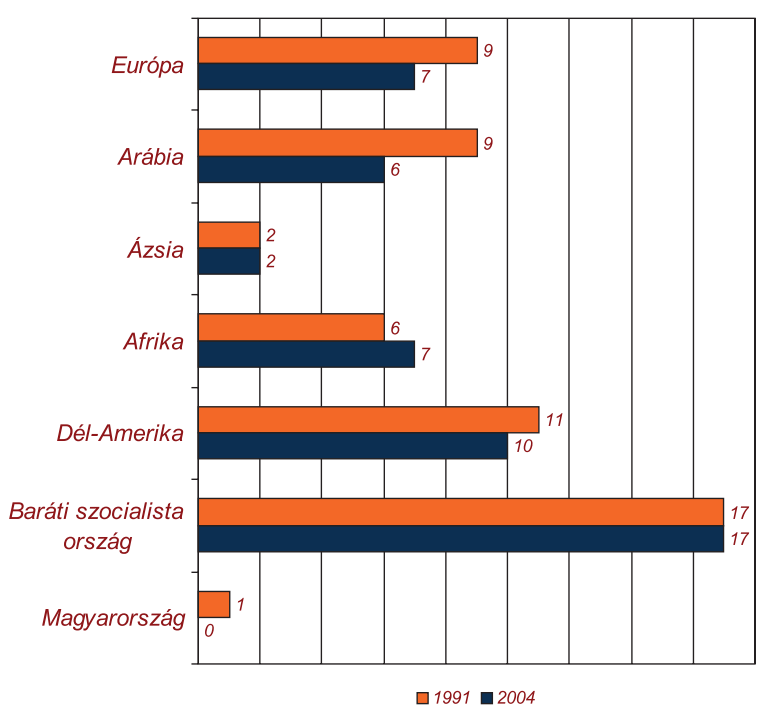

A kitüntetések származási hely szerinti megoszlása. (Az illusztrációt készítette: Gyurákovics Norbert)

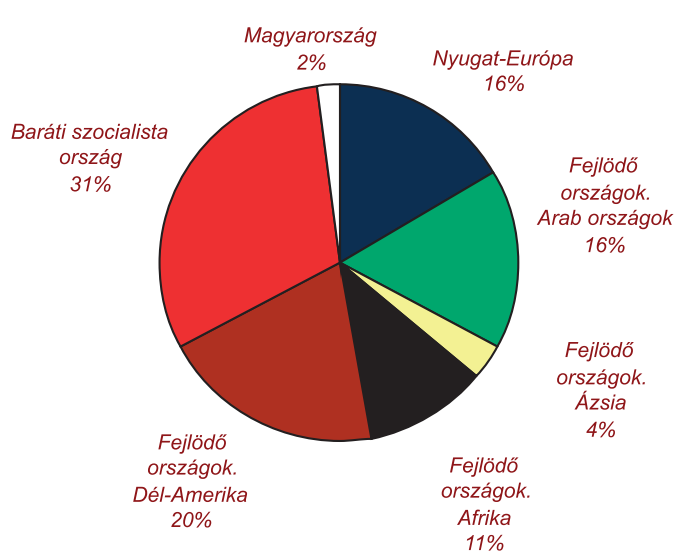

1991

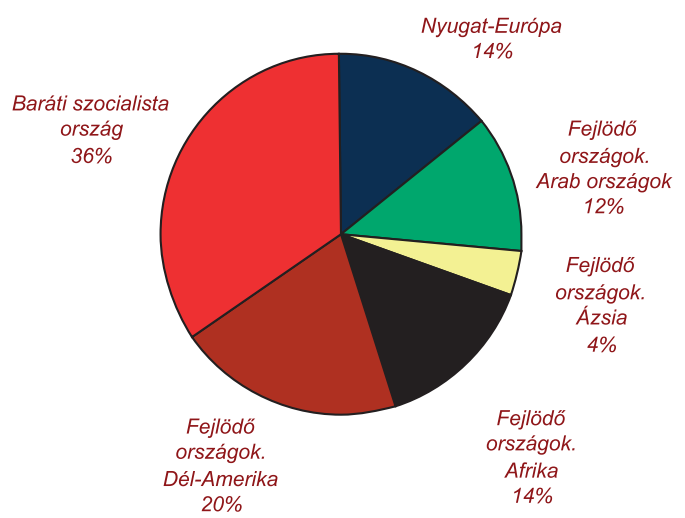

A kitüntetések származási hely szerinti százalékos megoszlása. (Az illusztrációt készítette: Gyurákovics Norbert) 


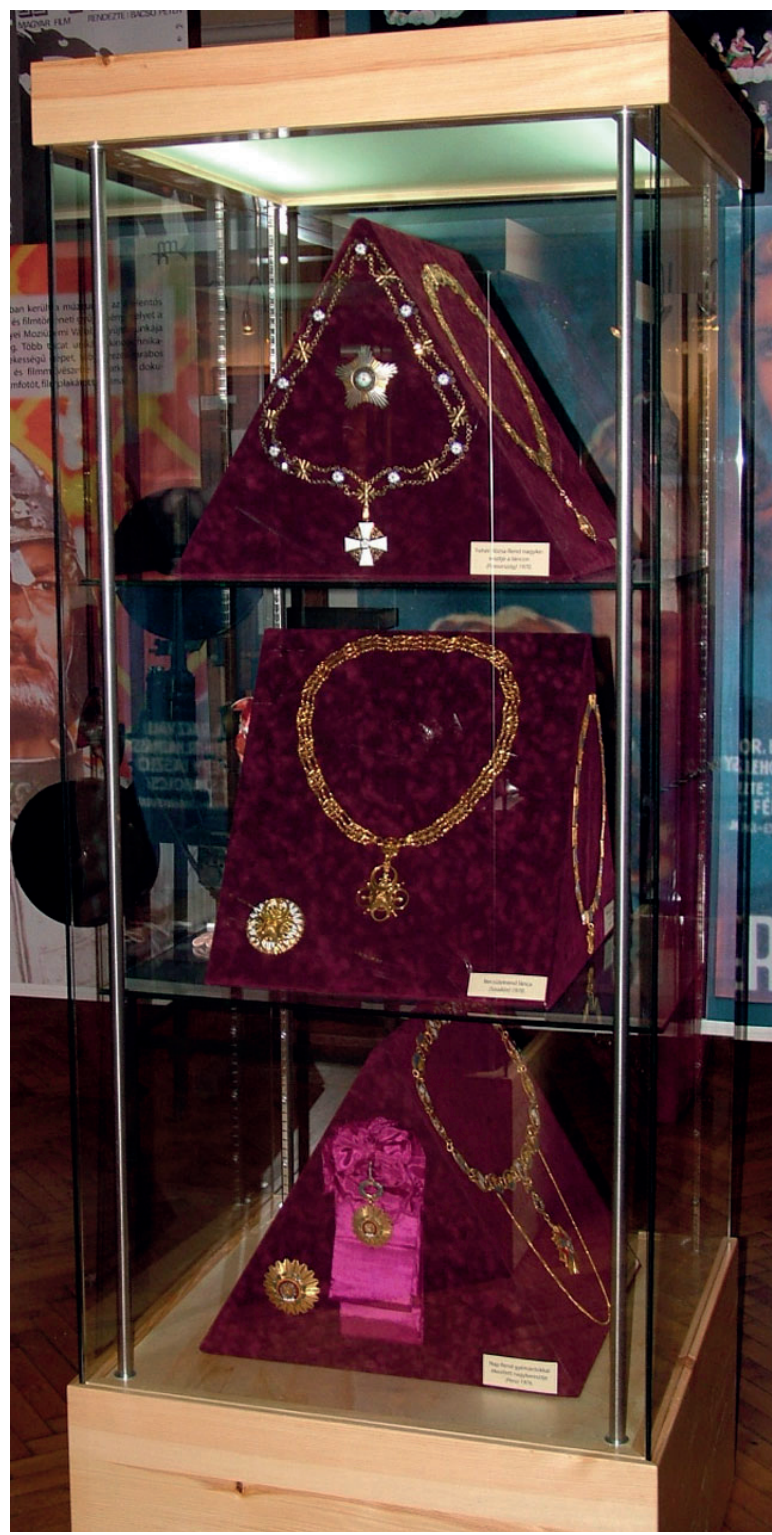

Válogatás Losonczi Pál államfői kitüntetéseiből. Részlet a Somogyország öröksége - 100 éves a múzeum címü jubileumi emlékkiállításból, 2009.

legmagasabb kitüntetésnek számító Szocialista Munka Hőse kitüntetéssel, kitüntető címmel és a vele járó Magyar Népköztársaság Érdemrendjével ismerik el. ${ }^{15}$

15 A Szocialista Munka Höse kitüntetést és kitüntető címet 1953-ban alapította az országgyülés a szocializmus építésében, az állam vezetésében végzett több évtizedes kiemelkedő munka elismerésére. A cím adományozásával 1964-ig együtt járt a Magyar Népköztársaság Érdemrendje elnevezésű kitüntetés adományozása is. (Ez utóbbit Losonczi Pál 1979-ben is megkapta.) Az 1953-ban alapított legmagasabb adományozható kitüntetés első tulajdonosa lett. A kitüntetetéssel nyugdijkiegészítés járt, ill. nyugdíjminimum, ha nem volt meg a kellő szolgálati idő.( Erről Id. Magyar Népköztársaság kitüntetései. Szerk.: dr. Besnyő Károly. Bp., 1979. Közgazdasági és Jogi Kk.16. p., ill. Komiszár Dénes: Mezőgazdaság és protokoll. Losonczi Pál kitüntetései a sajtó tükrében.= Somogyi Múzeumok Közleményei. Szerk.: Winkler Ferenc. Kaposvár, 2007.92. p.)
A Losonczi iránt egyre inkább megnyilvánuló országos figyelmet szakmai-politikai tagságai jelzik. A Sztálin halála utáni politikai helyzetben, az 1953-as parlamenti választásokon mandátumot nyer, 1954-ben az MDP III. kongresszusán tagja a küldöttek választotta elnökségnek. A kongresszus első napján szót kap, ${ }^{16}$ a zárónapon pedig az MDP Központi Vezetőségének póttagjává választják. A hatalom közelébe kerül. 1954-től a Termelöszövetkezeti Tanács elnökségi tagja, ${ }^{17}$ majd a Hazafias Népfront 1954. október 23-24-i alakuló kongresszusán a 105 tagú Országos Tanács tagjává választják, kifejezésre juttatva, hogy a Nagy Imre nevével fémjelzett „új szakasz" is igényt tart rá.

1956. március idusán Losonczi „a barcsi Vörös Csillag Termelőszövetkezet kiemelkedően jó irányításáért" újabb elismerést kap: a Kossuth-díj III. fokozatát, amelyhez 20.000 forintos pénzjutalom is jár. ${ }^{18}$

A Rákosi-korszak végére Losonczi a barcsi téesz elismert, sikeres elnöke. Gyakorlati ember. Alulról jövő, tehetséges, választott vezető, akire immár az országos politika felfigyelt.

A forradalom idején Losonczi Pál nincs a fővárosban. Arról, hogy mi történt vele kapcsolatban, keveset tudunk. Az 1956-os forradalom Somogyban címü forráskiadványban (Kaposvár, 1995.) a névmutató segítségével találunk rá. Somogy az idő tájt forrongó agrármegye. Az elégedetlenség is agrárvitával indul. ${ }^{19}$ Vidéken a népharag az első napokban emlékműveket dönt, forradalmi bizottságok megalakítását eredményezi. Október 30-án pedig a kaposvári tüntetők a pártbizottság elé vonulva elérik a helyi pártvezetők lemondatását, majd a pártbizottság épületében tartózkodó pártbizottsági tagok és munkatársak, köztük Losonczi Pál is (épp ott tartózkodott) ún. „védőőrizetbe” kerülnek, a tüntető tömeg a megyei börtönbe kíséri őket. ${ }^{20}$ Később, a Somogyország címü lap december 28-i számában, azaz jóval a forradalom leverése után, olvasói levélben utalás található a Losonczi-féle szövetkezeti politikára, az azzal való szimpatizálásra. Az olvasó szóvá teszi, hogy „a tsz-ek eddigi, alapjaiban helytelen formájáról a barcsi tsz. atyamestere, a Kossuth-díjas Losonczi Pál mondott lesújtó kritikát." s ezek után „olyan embereknek kell kezükbe venniük a falusi szövetkezés ügyét, akik a

16 Beszédében Losonczi a termelőszövetkezetek szétverése ellen emelt szót. Ugyanakkor hangsúlyozta az egyéni gazdákkal való jó viszonyt. Saját eredményeikről szólva közérthetően beszélt a premizálásról és a háztáji földek méretének szabályozásáról. (A Magyar Dolgozók Pártja III. kongresszusának jegyzőkönyve. Szikra 1954. 193-198. p.)

17 A minisztertanács mellett müködő javaslattevő, előkészítő, koordináló és ellenőrző feladatkörrel felruházott szerv, amelyet a kormányfő vezetett.

18 Erről Id. Magyar Közlöny. 1956. március 16.; 1956. évi Kossut-díjasok. = Szabad Nép. 1956. március 16.; Az alkotó munka megbecsülése. $=$ Szabad Nép. 1956. március 16.; Törvények és rendeletek hivatalos gyűjteménye 1956. Közzéteszi az Igazságügyminisztérium közreműködésével a Magyar Forradalmi Munkás-Paraszt Kormány Titkársága. Bp., 1957. 143. p.; Az 1948. évi XVIII. tc. alapította kitüntetés 1955. 2. tvr. kibővítette a kitüntethetők körét.

19 Ld. Márkus István: Somogyi összegzés című cikkének 1956. október 19-i kaposvári vitája

20 Szántó László: Az 1956-os forradalom Somogyban. Válogatott dokumentumok. Kaposvár, 1995. Somogy Megyei Levéltár kiad. 17. p. és 131. p 


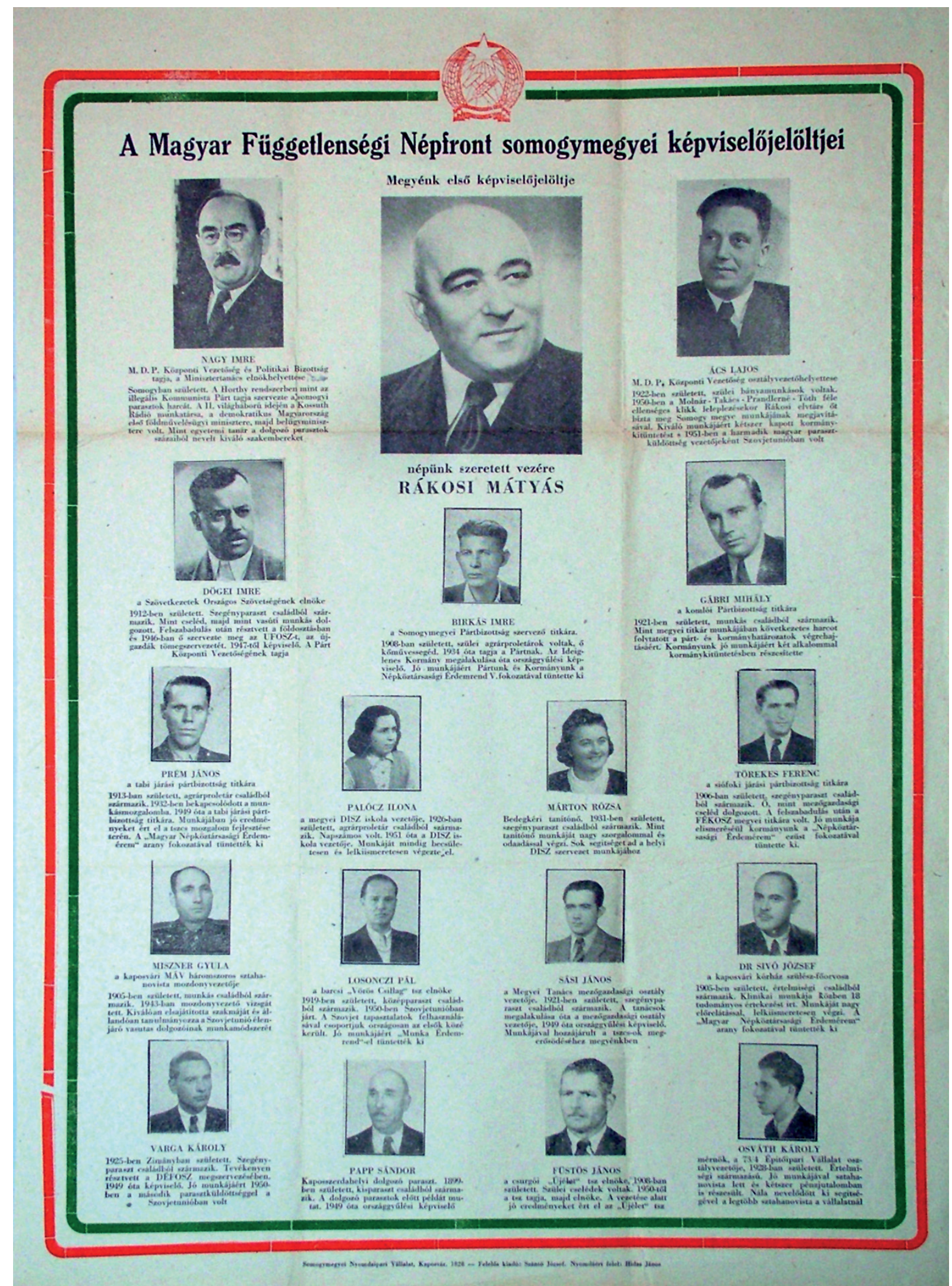

Választási plakát, 1953. (Rippl-Rónai Múzeum Újkortörténeti gyüjtemény) 
szövetkezeti szervezést nem a Rákosi-Gerő-féle pártiskolában tanulták." Ezek az emberek pedig nem mások, mint „a régi szövetkezeti értelmiségiek, akiket a Rákosi-érában annyira elnyomtak és akik ilyen körülmények között is alárendelt beosztásban is értek el eredményeket”. ${ }^{21} \mathrm{E}$ dokumentumok tükrében elmondható, hogy a forradalom idején Losonczi személye különösebben nem volt érintve, pusztán ún. „védő őrizetben” volt.

A forradalom leverése után az ország új vezetése a nemzetközi elszigeteltség és a megtorlás belpolitikai légkörében, jobb- és baloldali szélsőségek elleni küzdelmet folytatva a gazdaság helyreállítását, az életszínvonal fejlesztését, a tömegek megnyerését tủzi ki célul.

Az 1957-es pártértekezleten Losonczi Pál személye ismét előtérbe kerül, a KB tagjává választják. ${ }^{22}$

Az agrárkérdést az MSZMP 1959-es pártkongreszszusáig folyamatosan napirenden tartják. Számos pártdokumentum születik a termelőszövetkezeti mozgalom továbbfejlesztéséröl, 1957 novemberétől folyik a tapasztalatszerzés a gyakorlatban is. A helyszíni tájékozódásban (Csongrád, Fejér, Heves, Somogy és Szolnok megyében) 12 KB-tag és póttag, köztük Losonczi Pál is szerepet kap. A barcsi Vörös Csillag Tsz. 1957. december 13-i zárszámadásán a kormány és a KB több tagja mellett Kádár is megjelenik. Beszédében a szövetkezeti mozgalom megerősítésére, az ellenséggel szembeni kíméletlen fellépésre, egyúttal a parasztság egyéni jövedelmeinek kívánatos növelésére helyezi a hangsúlyt. Losonczi álláspontját a gyakorlat látszik igazolni: előrelépést a gépesítésben, a szakképzésben, hangsúlyozva az egyéni ösztönző tényező szerepét. „... mindaz jó, ami előreviszi a termelést, növeli az árutermelést, és a tagoknak is az anyagi érdekeltségét növeli." ${ }^{23}$ 1958-ban megkapja a Szocialista Munkáért Érdemérem ${ }^{24}$ és a Munkás-Paraszt Hatalomért ${ }^{25}$ kitüntetéseket.

1959 elején másodszor is nekifog a hatalom a mezőgazdaság kollektivizálásának. Kezdetben Dögei Imre földművelésügyi miniszter irányítja a munkát. $A$ szovjet utat erőlteti, gyors és erőszakos kolhozosítást akar. Vele szemben Fehér Lajos, az MSZMP KB mezőgazdasági osztályvezetője markánsan eltérő álláspon-

21 Kiss Imre: Megint az éretelmiség legyen a bünbak? Somogyország 1956. december 28.= Szántó im. 312. p.

22 Tagja maradt 1989. február 21-ig. Losonczi az említett 1957-es értekezlet második napján szót kapott. Helyesnek tartotta a kormány agrárfejlesztési intézkedéseit. Az ellenforradalom bűnei között elsősorban a téeszek szétverését ostorozta. A téeszek felbomlásával kapcsolatban azonban hibásnak tartotta az 1955 utáni erőltetett újraszervezést is.

23 A Magyar Szocialista Munkáspárt Központi Bizottságának 19591960. évi jegyzőkönyvei. Szerk.: S. Kosztricz Anna, Némethné Vágyi Karola, Simon István, Soós László. Magyar Országos Levéltár. 1999. 335-340. p.

24 A kitüntetést 1953-ban, a szocializmus építésében kimagasló érdemeket szerzett polgári személyek elismerésére alapította az országgyülés. 1963-ig adományozták. Külleme 1954-ben és 1957-ben megváltozott. Erről Makai-Héri: Kereszt, érem, csillag. kitüntetések a magyar történelemben. Helikon Kiadó, Budapest, 2002. 236. p. vagy Bodrogi Péter - Molnár József - Zeidler Sándor: Nagy magyar kitüntetéskönyv. Szerk.: Rácz Árpád. Rubicon K., Budapest, 2005. 204-205. p.

25 Az 1956-os ellenforradalom leverésében, az ország rendjének megszilárdításában kifejtett tevékenység elismerésére 1957-ben alapította a Forradalmi Munkás-Paraszt Kormány. Makai-Héri im. 239. p., ill. Nagy Magyar kitüntetéskönyv 222. p. tot képvisel. Rainer János frappáns megfogalmazása szerint Fehér Lajos „lappangó Nagy Imre követő volt, aki ugyan megtagadta a kivégzett miniszterelnököt, de politikájából igyekezett átmenteni valamit." Fehér azt követelte, hogy a kollektivizálás alatt ne csökkenjen a mezőgazdasági termelés, ami ekkor egyértelmúen a sztálini módszer kritikáját jelentette ${ }^{26}$ A szélsőségeket Kádár János nem tolerálta. Dögeit leváltották, Fehérnek pedig önkritikát kellett gyakorolnia.

Kádár célja az '56 után fokozatosan konszolidálódó hazai politikai és gazdasági közélet megszilárdítása, a felső vezetés friss és erkölcsileg támadhatatlan erőkkel való „feltöltése”, egyben a munkás-paraszt szövetségi politika erősítése volt. Így került előtérbe újra Losonczi Pál.

A sikeres téeszelnök 1960-ban földmúvelésügyi miniszter lesz. Személye több szempontból is ideális választásnak tűnt. 1956 előtt nem kompromittálódott. Ugyanakkor az általa alapított barcsi szövetkezet sem 1953-ban (Nagy Imre első miniszterelnökségekor), sem 1956 novemberében nem oszlott fel. Az ilyen szövetkezetek ritkák voltak, felértékelődtek a hatalom számára. Losonczi nem a szovjet mintát másolta, képes volt egyben tartani a szövetkezetét. A munkaegység alapú elszámolás helyett olyan díjszabási rendszert állapított meg, amelyben a tagok jobban megtalálták a számításukat. Ez ellentétes volt a Dögei eröltette szovjet mintával, ezért számított 1959-ben Losonczi is - ahogy Kádár fogalmazott - fekete báránynak. Paraszti származása, gyakorlatban alkalmazott módszerei, viszonylag fiatal életkora (41 éves) s ugyanakkor régi párttagsága mind-mind személye mellett szóltak.

\section{A miniszter}

Losonczi vezetésével 1961 végére lezárul a kollektivizálás, a Barcson használt modellt több helyen engedélyezték. Sikerült megakadályozni a mezőgazdasági termelés összeomlását. A munkában a gyakorlatias, tapasztalt Losonczi partnere és egyúttal felettese is az 1959-ben KB-titkárrá, majd 1962-ben miniszterelnök-helyettessé választott elméleti szakember, Fehér Lajos. ${ }^{27}$

Losonczi Pál otthonosan mozog az agrárium világában. Ismeri a földművesek életét, gondolkodását, de számítani kíván a tanult emberek munkájára is. Minisztersége alatt válnak önállóvá az agrártudományi egyetemek fakultásai, Sopronban erdészeti és faipari egyetem létesül (1962), a gödöllői egyetem alapkövét ő, a miniszter helyezi el, hogy a mezőgazdasági gépészmérnöki kar kiépülhessen. 1963-tól indul a mezőgazdaság rendszeres, évi támogatása, folyamatosan jelennek meg az ár- és hitelpolitikai, valamint a tervezési jogszabályok.

26 Mint ismeretes, a Szovjetunióban az erőszakos kolhozosítást hatalmas éhínség követte.

27 Együtt dolgoztak az 1959-ben létrehozott Agrárpolitikai Bizottságot felváltó Mezőgazdasági Bizottságban (a vezetője Fehér Lajos, Losonczit pedig 1960-ban választják be a testületbe), illetve az 1966-ban létrehozott Szövetkezetpolitikai Munkaközösségben (elnöke ugyancsak Fehér Lajos, Losonczi pedig testületi tag volt egészen 1980 áprilisáig). 


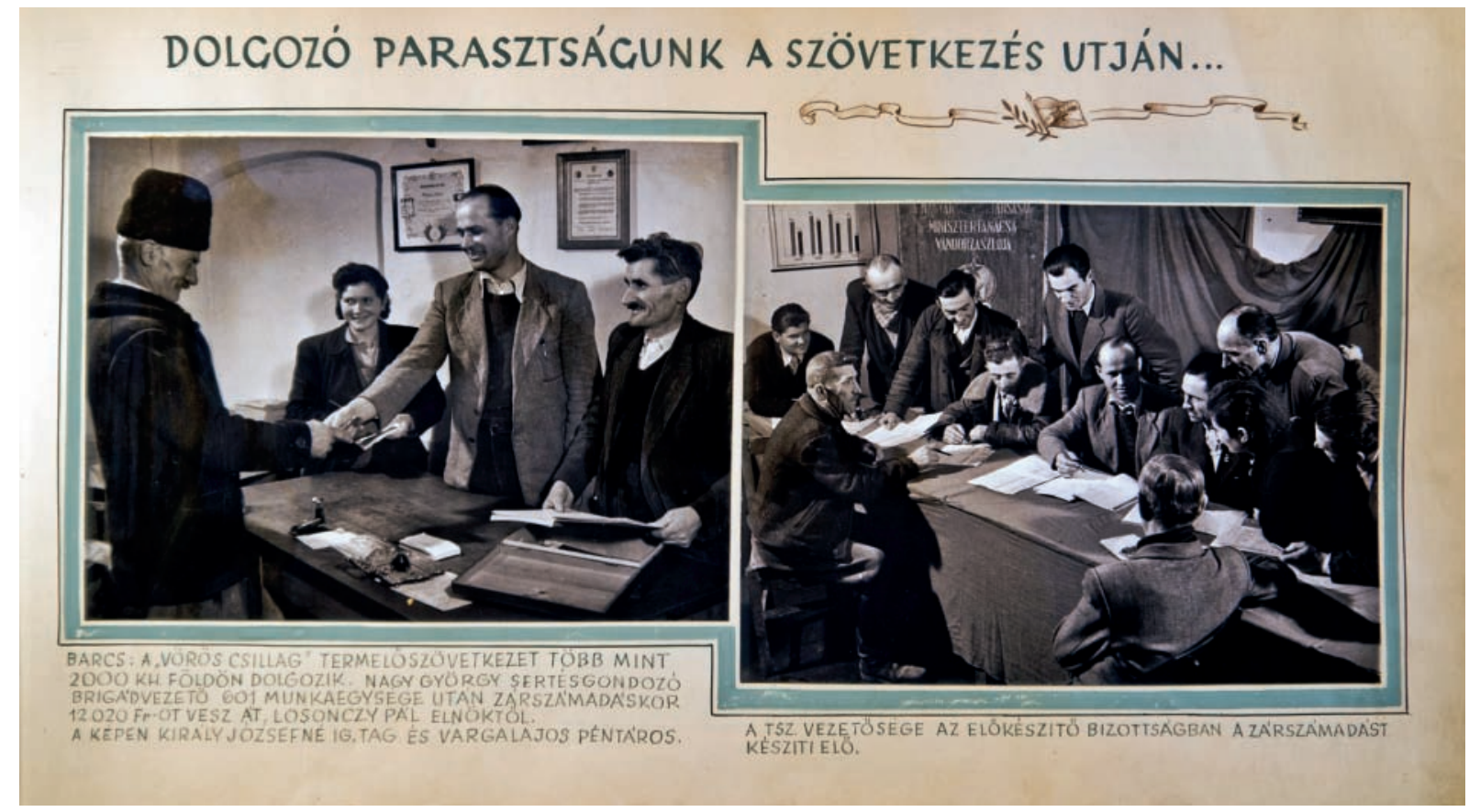

Propaganda-fotók a „Somogy megye a felemelkedés útján” címü fényképalbumból, 1950-es évek első fele (Rippl-Rónai Múzeum Újkortörténeti gyüjtemény)

Hét éves minisztersége alatt Losonczi Pál kitüntetést nem kapott. Külföldön viszont - Dániában (1961) és Lengyelországban (1962) - járt.

Földművelésügyi miniszterként tényleges politikai szerepe a szövetkezeti reform végrehajtása volt. ${ }^{28} \mathrm{~A}$ folyamat lezárásaként létrejövő 1967. III. és IV. törvényt, az MSZMP KB 1966-ban elfogadott új gazdasági mechanizmus irányelveinek megvalósulását azonban már egy magasabb pozícióból szemlélhette.

Az új gazdasági mechanizmussal próbálkozó kádári személyzeti politika eredményeként, 1967. április 14-én, az országgyűlés alakuló ülésén átfogó személyi változtatásokra került sor. ${ }^{29} \mathrm{~A}$ Földművelésügyi Minisztériumot átszervezik, új nevet is kap. ${ }^{30}$ Losonczi nem marad a tárca élén, a legmagasabb közjogi méltóság posztjára emelik, az Elnöki Tanács elnöke lesz.

28 A kolhozvonások leépítésével, a gépállomások felszámolásával helyettük közvetlenül a szövetkezetek gépesítésével, a szövetkezeti földtulajdon kialakításával, a háztáji gazdaságok erősítésével, a vállalatszerű gazdálkodás egyes elemeinek megvalósításával kerül sor az átalakulási folyamat lezárásaként az 1967. évi III. és IV. törvény előkészítésére.

29 Az Elnöki Tanács elnöke pozíciójába Losonczi Pál kerül (Dobi István helyére), Fock Jenő lesz a minisztertanács elnöke Kállai Gyula helyett, Kállait ugyanakkor Vass Istvánné helyett az országgyűlés elnökévé választják. Az Elnöki Tanács titkári posztján Cseterki Lajos váltja Kiss Károlyt. A reformszellemű kormányban Fehér Lajos mellett elnökhelyettes lett Ajtai Miklós, a Tervhivatal elnöke és az addigi pénzügyminiszter Tímár Mátyás. A reform híve az új pénzügyminiszter, Vályi Péter is. Ld. Bolvári-Takács Gábor: Eszme és föld. Vázlatpontok Losonczi Pál agrárpolitikusi portréjához.= Zempléni Múzsa. 2006. 2. sz. 21. p.

30 Az új elnevezés Mezőgazdasági és Élelmezésügyi Minisztérium, ugyanis a Földművelésügyi minisztériumot összevonták az élelmezésügyi tárcával. Az új miniszter pedig a reform előkészítésében tevékenyen részt vevő Dimény Imre lett. Erről Bolvári-Takács Gábor: Eszme és föld. Vázlatpontok Losonczi Pál agrárpolitikusi portréjához.= Zempléni Múzsa. 2006. 2. sz. 21. p.
Paraszti származásúként és Kádár „találmányaként" tökéletesen megfelel a posztra. A negyvenes évek közepétöl hagyomány volt ugyanis, hogy a teljesen protokolláris államfői funkciót paraszti származású politikus töltse be. Losonczi egy volt kisgazdát, Dobi Istvánt váltotta az Elnöki Tanács élén. „Igazi kádári találmány volt, egy sikeres Tsz-elnök, önálló nézetek nélkül." - nyilatkozta 2005-ben a sajtónak tömören Rainer János. Megállapítását igazolni látszik, hogy Losonczi Pál a pártnyilvánosság előtt az 1959-es pártkongresszustól kezdve az 1988-as pártértekezletig egyszer sem szólalt fel.

Kádár számára Losonczi azért is volt jó választás, mivel politikai vetélytársként szóba sem jöhetett. Losonczit nem ambicionálta a hatalom. Miniszterként is Kádár embere volt, centrumpolitikus ${ }^{31}$, aki önálló politikai bázissal nem, legfeljebb politikai hátországgal (Somogy megye) rendelkezett. Életkora (48 év) miatt akár évtizedekre számolhattak vele. Paraszt származása pedig hitelesen folytatta a Dobi-féle népfrontvonalat.

\section{Az Elnöki Tanács Elnöke}

Losonczi Pál a Magyar Népköztársaság Elnöki Tanácsának elnökeként államfő volt. 1967 és 1987 között töltötte be ezt a tisztséget. A társadalmi berendezkedés miatt azonban a két tisztség közé mégsem lehet egyenlőségjelet tenni.

Hogy Losonczi mozgásteréről képet alkothassunk, röviden érintenünk kell a szocialista kori államfői testü-

31 Személyét sokan már sokféle válogatott jelzővel illették. Volt középszerü bürokrata, intellektuálisan jelentéktelen személy, külsőre parádés kocsishoz is hasonlították, de volt De Gaulle gorillája kinézetű is. 
let mibenlétének, jogkörének lényegét. ${ }^{32} \mathrm{Az}$ elnök elvben három fontos területet felügyelt, ám ezek a gyakorlatban többé-kevésbé névleges feladatköröknek bizonyultak. A testület a parlament utólagos jóváhagyásával törvényerejü rendeleteket alkothatott. Ezeket azonban az MSZMP központi szerveiben készítették elő, az Elnöki Tanácsban valódi vitákat nem tartottak. A kegyelem gyakorlásának jogával kapcsolatban papíron az Igazságügyi Minisztérium, a gyakorlatban a Belügyminisztérium készítette elő a döntéseket. Maradt a reprezentatív funkció: magas rangú külföldi politikusok, delegációk itthoni fogadása és Magyarország államfői szintű külföldi képviselete.

1967-ben Losonczi Pál elérte karrierje csúcsát. Ám olyan funkciót vállalt, amelyhez semmit sem értett: sem szakképzettsége, sem diplomáciai ismeretei nem voltak. Kádárnak ilyen tulajdonságokkal rendelkező elnökre nem is volt szüksége. A pártfegyelem és az egyéni ambíció kizárta a poszt visszautasításának lehetőségét.

Losonczi tehát nem volt (nem is lehetett) önálló hatalmi-politikai tényező. 1975-ig például nem volt PBtag, államfői funkciója ellenére a legfontosabb politikai döntésekröl is csak utólag kapott tájékoztatást. ${ }^{33} 1969$ től a PB ülésein már állandó meghívottként vesz részt. A napirendi jegyzékekből kiderül, hogy a PB ülésein az államfő minden külföldi útjáról beszámol, nyilatkozatait jóváhagyatja, még az országon belüli látogatásairól, meghívásairól is jelentést tesz. 1975-re már feltehetőleg kínossá vált, hogy nem tagja a legfelső pártvezetésnek. A magyar külpolitika sikerei miatt azonban egyre fontosabbá vált, hogy az államfői funkcióval együtt járó protokolláris és nemzetközi feladatok ne nélkülözzék a legmagasabb szintű párttestületi tagságot.

Tekintettel arra, hogy a belpolitika alakítása kívül esett Losonczi Pál hatáskörén és személyes lehetőségein, államfői tevékenysége jórészt a külkapcsolatok alakításában való részvételre korlátozódott. ${ }^{34}$ Annak eldöntése is párthatáskörbe tartozott, hogy mely államok vezetőit hívjuk meg magyarországi látogatásra, illetve mely meghívásokat milyen szinten fogadunk el. Az államfő számára a pártállam keretei között kijelölt mozgásteret külföldi útjai jelzik.

Losonczi első külföldi vendége 1968 májusában a mongol államfő volt, első külföldi útja ugyanez év júniusában az NDK-ba vezetett. Walter Ulbricht pártfőtitkárállamfő 75. születésnapján képviselte Magyarországot.

\section{Magyarország „utazó” elnöke}

Az ENSZ és Magyarország kapcsolatának 1963-as normalizálása előtt a Kádár-rendszer nagyfokú nemzetközi elszigeteltségtől szenvedett. Ezen a helyzeten Kádár két módon igyekezett enyhíteni: a szomszédos szocialista országok bizalmának elnyerésével, illetve kapcso-

32 Az összehasonlitást sokan megtették már előttem, részletesen felhívva a különbségekre a figyelmet. (Erről Bolvári-Takács Gábor: Csendben a csúcson. Vázlatpontok Losonczi Pál államfői portréjához. Zempléni Múzsa. VIII. évfolyam 3. (31.) szám - 2008. ösz, 13-14. p

33 Például az 1968-as csehszlovák válsággal kapcsolatos pártközi megbeszélések előkészítésekor.

34 A külügy, bár a miniszterelnök hatáskörébe tartozott, valójában ugyancsak pártirányítás alatt állt. latok létesítésével a harmadik világ szovjetbarát országai és az el nem kötelezett országok felé. A Szovjetunió iránti lojalitás és a szovjet irányvonalhoz való feltétlen alkalmazkodás - természetesen - mindvégig a kádári külpolitika alapelve maradt.

A 60-as évek második fele, a 70-es évek eleje - a harmadik világ országainak függetlenedése nyomán - a diplomáciai kapcsolatok ugrásszerü kiszélesedésének időszaka Magyarországon. Losonczi államfői periódusának első tíz évében hazánk 53, főleg afrikai, dél-amerikai és ázsiai állammal létesít diplomáciai kapcsolatot (pl. Angola, Kolumbia, Líbia, Mexikó, Peru stb.), de európai országokkal is (Írország, Málta, NSZK, Portugália, Spanyolország). Ezzel párhuzamosan, a 60-as évek végétől mind nagyobb méretet öltött a magyar államférfiak külföldi látogatásainak sorozata.

Nagy jelentőséggel bírt, hogy a 60-as évek végétől formálódó önállóbb magyar külpolitika a nyugati világ felé is nyitott. Egyre nagyobb hangsúly tevődött a nemzeti szempontból előnyös külkapcsolatokra, a mozgástér fokozatos tágítására. A folyamat hátterében a modern világgazdasági folyamatokhoz való csatlakozás igénye állt. Az ország első partnerei ebben, a kétpólusú világ határán elhelyezkedő két semleges ország: Finnország és Ausztria lett.

A NET elnöke külföldi látogatásai során illetve külföldi közjogi méltóságok magyarországi fogadása alkalmával a diplomáciai protokoll szerint magas külföldi kitüntetésekben részesült. Múzeumunk gyűjteményében lévő rangos külföldi kitüntetések, érmek nyolcada származik Nyugat-Európából (Finnország, Ausztria, Spanyolország, Portugália, Ciprus), ötöde a Szovjetunióból, közel egyharmada baráti szocialista országból (Csehszlovákia, Lengyelország, Bulgária, VDK, KDK, Mongólia, Kuba), a többi, kb. a fele az ún. fejlődő (afrikai, latin-amerikai, ázsiai) országokból való.

Az elnök elhunyta alkalmából a bulvársajtó előszeretettel emlegette az elnöki utazások egzotikumát (utalva őslakosok rituális táncára, teknősháton való lovaglásra, éhínség sújtotta népek fényüző diktátorainak pompájára). Az elnöki találkozók közül leginkább a nem szalonképes, visszatetszést keltő politikusokat emelték ki: a véreskezű ugandai diktátort, Idi Amint, az emberevéssel is gyanúsított, kegyetlen Jean-Bédel Bokassát, Fekete-Afrika leghírhedtebb diktátorát, a Közép-afrikai Köztársaság császárát. ${ }^{35} \mathrm{Az}$ országos média sajnálattal vette tudomásul 2005-ös „érdeklődése” alkalmából, hogy ezekből az államokból sem aján-

35 A Bokassával való kapcsolat lejárató mivoltára példa az 1981 es francia elnökválasztás. Giscard d'Estaing francia konzervatív politikus 1973-ban pénzügyminiszterként állítólag két nagy értékű gyémántot kapott a Közép-afrikai Köztársaság elnökétől, Bokassától. A sajtó sugallata szerint az ajándék befolyásolta Giscard későbbi politikáját. Franciaország kezdetben ugyanis támogatta a diktatúrát, de miután 1979 áprilisában 100 iskolás gyereket lemészároltak Bokassa fegyveresei, a francia titkosszolgálat a helyi ellenzékkel szövetkezve megdöntötte a diktátor uralmát. A sajtó egy hónap múlva nyilvánosságra hozta a gyémántokról szóló dokumentumokat. A francia elnök tagadta, hogy személyes tulajdonába vette volna a gyémántokat. Ráadásul, protokoll szerint a hivatalos látogatáson kapott ajándék az országot illette volna meg. (Erröl Id. Retro évek. Így éltünk 1981-82. Szerk.: Sz. Soós Éva. Média Service Zawada Kft. kiad. Bp., 2012. 39. p.) 
déktárgy, sem kitüntetés nincs (korábban sem volt) a gyűjteményben. ${ }^{36} \mathrm{~A}$ sajtó a szenzációt kereste, hangját az egyoldalú elfogultság jellemezte.

Míg, ha a kitüntetéseket, mint történeti forrásokat vizsgáljuk, a hazai diplomácia történetének finom részletei tárulnak elénk.

\section{A finn Fehér Rózsa Érdemrend nagykeresztje a láncon}

Az eddig elmondottakra jó példa mindjárt időrendben az első, az 1969-ben kapott finn kitüntetés. Érdemes róla részletesebben szót ejtenünk, bemutatva egyúttal a kitüntetések muzeológusi feldolgozását is. Egyértelművé válhat így a különbség: mennyire másként gondolkodunk, mint a propaganda. Hiszen amellett, hogy leírjuk a kitüntetést (az érdemrend alapításának körülményeit, azt, hogy milyen érdemek elismerésére hozták létre, kik kaphatták, milyen az érdemrend felépítése, mit fejeznek ki szimbólumai, fontosak továbbá a kivitelezés, gyártás, anyag, technika, adjusztálás adatai, az, hogy kiknek adományozták, az aktuális aukciók szerinti értékbecslések, stb.), fontos ismernünk az adományozó ország történetét, az adományozó személyt, elemezni a diplomáciai előzményeket, az időpontot, amelyben a diplomáciai találkozó ill. az adományozás történt.

A finn kitüntetés esetében szerencsénk van, nincs nehéz dolgunk. A finn-magyar kapcsolatokra vonatkozó szakirodalom a finn nagykövetség jóvoltából a kutató rendelkezésére áll. ${ }^{37}$

Mint ismeretes, 1966-1967 körül a Kádár-vezette ország önállóbb, aktívabb külpolitikába kezd, mivel a nyugati országokkal való gazdasági és műszaki kapcsolatok fejlesztése, valamint a hitel- és kölcsönfelvétel fontossá vált az ország számára.

A többi szocialista ország veszélyesnek tartja a magyar gazdasági reformot, azzal a kritikával illetik Magyarországot, hogy a kapitalizmus felé tart. Ebben a helyzetben a hagyományosan jó magyar-finn kapcsolatok a kitörés lehetőségét biztosították.

A Finnország és Magyarország közti viszony 1956 utáni fontos eseménye Kekkonen államelnök 1963. május 12. és 15. közötti nem hivatalos látogatása volt. Ő volt az első nyugati államfő, aki ellátogatott a kádári Magyarországra.

Urho Kaleva Kekkonen, aki az 1928-as budapesti finnugor kultúrkongresszuson járt már Magyarországon, eredetileg agrárpolitikus volt. 1963-ban Jugoszláviából, Titótól érkezik Magyarországra. Ez a látogatás nem volt hivatalos, és Kekkonen ezt mindenképp

36 Ejthettek volna szót olyan harmadik világbeli elnökröl is, akinek mindmáig a nevét viseli országa egyetlen egyeteme, halálának napja pedig - az ottani rendszerváltás ellenére - máig az egyik legfontosabb nemzeti ünnep az országban. S ne feledkezzünk el arról sem, hazánk sem volt a világ élvonalbeli országa. Losoncziék ezt még így fogalmaztak meg: „a Magyar Népköztársaság, közepesen fejlett, természeti erőforrásokkal szűkösen ellátott szocialista ország. Gazdaságának nyitottsága, szerkezete és adottságai révén különösen érzékenyen érintik a világgazdasági változások."

37 Rokoni körben. A magyarországi finn képviselet története. Szerk.: Jakoo Sivers. Bp., 2010. a Finn Nagykövetség kiad.

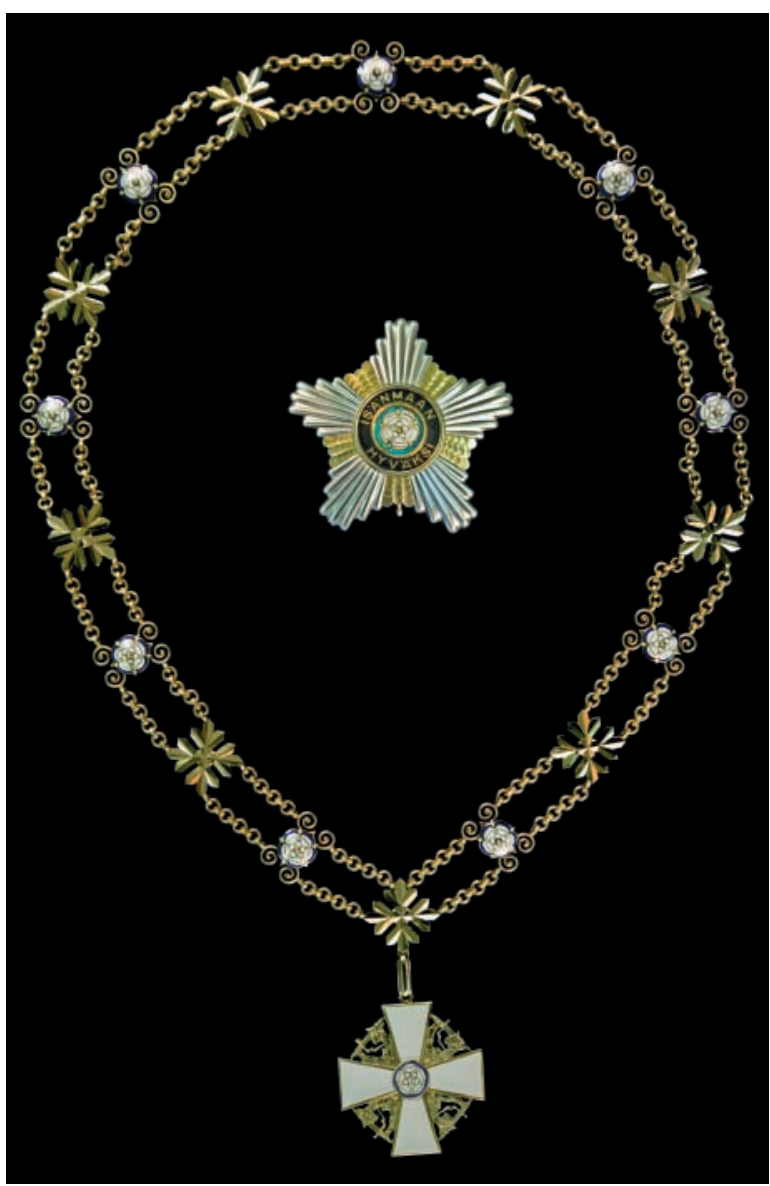

A finn Fehér Rózsa Érdemrend nagykeresztje a láncon, 1969. (Rippl-Rónai Múzeum Újkortörténeti gyüjtemény)

hangsúlyozni is kívánta. A Jugoszláviában járt finn küldöttségből csak néhányan kísérték el az elnököt Magyarországra. Mindezek ellenére Kekkonen a teljes magyar politikai elittel találkozott, beleértve Kádárt is. A magyarok politikáról is próbáltak tárgyalni a finn elnökkel, de kevés sikerrel jártak. Kekkonen biztosra akart menni - nehogy kritikára adjon okot - mindenképp meg akarta őrizni az út nem hivatalos jellegét. A finn államfő elégedett volt a látogatással. Ahogy a naplójában írja, Kádár becsületes, egyenes stílusa jó benyomást tett rá. Losonczi Pál kíséretében a Hortobágyra is ellátogatott. Jó véleménnyel volt a magyar mezőgazdaságról. 1969-ben aztán már hivatalosan és részletesebben megismerkedett a magyar viszonyokkal. A bábolnai mintagazdaságban megjegyezte Kádárnak, hogy ha néhány száz ilyen színvonalú gazdaság működne Magyarországon, könnyedén leköröznék a kapitalista mezőgazdaság vívmányait.

Az 1960-as évek végére megélénkültek a két ország közti kapcsolatok. A csúcs Kekkonen elnök 1969es hivatalos látogatása volt. Ekkor írták alá a két ország közti gazdasági, műszaki és tudományos együttműködési egyezményt, valamint 1970. január 1-jével megállapodtak a vízumkényszer feloldásáról. Mindezt 
a '70-es években számos diplomáciai és kulturális megállapodás követte. ${ }^{38}$

Ezeknél sokkal fontosabb az a tény, hogy Finnország politikai okból is kiemelkedő partnert jelentett a magyarok számára. Kekkonen elnök külpolitikai irányvonalát - a hídverő szerepét betölteni a Kelet és a Nyugat között - a magyarok kitörési lehetöségként értékelték. Amikor 1969 májusában a finn kormányzat önálló javaslatot tett az Európai Biztonsági és Együttműködési Értekezlet összehívására, Magyarország aktívan a finn javaslat mögé állt. Az invitálás minden európai fél számára szólt, beleértve mindkét Németországot. A meghívottak közé tartozott az Egyesült Államok és Kanada is. Kekkonen Helsinkit ajánlotta a konferencia helyszínéül.

Ezután Magyarország és Finnország legfelső politikai vezetői rendszeresen találkoztak egymással. 1971-ben Fock Jenő miniszterelnök, Péter János külügyminiszter és Losonczi Pál, az Elnöki Tanács elnöke utazott Finnországba. Két évvel később, 1973-ban Kádár finnországi látogatására került sor.

Az 1975. július-augusztusában megrendezett helsinki csúcstalálkozó óriási jelentőségű volt. Bár a hidegháborús frontvonalakat nem módosították, új utat nyitott a kelet-nyugati kapcsolatok fejlesztéséhez. Az 1975. augusztus 1-jén aláírt záródokumentum rögzítette a gazdasági és tudományos cserekapcsolatok élénkítését, ugyanakkor szólt az emberi jogok biztosításáról is. Ez utóbbi jelentősen megnövelte a kelet-európai politikai mozgalmak tevékenységét, és hozzájárult $-\mathrm{s}$ tegyük hozzá, hogy ezt Kádárék aligha így gondolták - az alig tizenöt évvel későbbi változások kialakulásához.

Az Európai Biztonsági és Együttműködési Értekezlet után Magyarország számára kinyílt a világ. A kelet-nyugati kapcsolatokban új fejezetet jelentő aktus elsősorban Kádár mozgásterét nyitotta meg, aki élt is a lehetőséggel. A nemzetközi sajtóban Kádár a körülményekhez képest maximális szabadság éllovasa lett, s ez az ország európai tekintélyét ugrásszerủen, jelentősen megnövelte.

Ezután Losonczi külföldi útjai is megszaporodtak, jóllehet nemzetközi téren továbbra sem tartoztak feltétlenül hatáskörébe a szocialista és a fejlett tőkés országok.

Mindezek ismeretében a kitüntetés a fenti ismeretekkel kerül meghatározásra (1. melléklet).

\section{Lappangó mütárgyak}

A Losonczi-gyűjtemény 1991-es, visszaadás előtti állapota a jelenleginél jóval gazdagabb volt. Nem kerültek vissza a Somogy megyei múzeumba az ajándéktárgyak (díszkardok, szobrok, ezüstből készült hajók, tálcák, ugyancsak ezüstböl készült teáskészlet, táncos felszerelés, elefántcsont-faragások, különféle iparművészeti tárgyak), látogatásai alkalmából kapott

38 A következő évben létrejött a konzuli egyezmény a két ország között. Az egyezmények növelték a Helsinki és Budapest közti forgalmat. 1976-ban a két ország tudományos akadémiája együttműködési megállapodást írt alá, amely intézményi szintre emelte a kétoldalú tudományos cserét és együttműködést. Ennek egyik formáját jelentették az ún. tudományos napok: az első ilyen rendezvényre Finnországban 1968 őszén került sor, majd 1979 májusában Magyarország következett, stb. színaranyból készült emlékérmek. De - sajnos - nincs a múzeum tulajdonában az a plakett sem, amely az elnök kiemelkedő nemzetközi szereplésére utal.

1983. szeptember 25-30. között Losonczi Pál New Yorkban az állam- és kormányfök Indira Gandhi kezdeményezte konferenciáján vett részt. Szeptember 28-án beszédet mondott az ENSZ közgyülése előtt. A világ előtt álló globális problémákról ejtett szót. Beszélt a leszerelés fontosságáról, felhívta a figyelmet a fejlett és kevésbé fejlett országok közti kiáltó ellentétre, s ezzel összefüggésben a világgazdasági egyensúly igazságos és demokratikus alapú átrendezésének szükségességére. ${ }^{39} 1985$. október 19-26. között ismét New Yorkban járt az ENSZ közgyűlése 40. ülésszakának egy részén és az ENSZ alapításának 40. évfordulós ünnepélyén, ahol 21-én beszédet is mondott. ${ }^{40}$ Losonczi ott jártának emlékére az ENSZ alapítása 40 éves évfordulójának plakettjét kapta. Az európai szocialista országok közül csupán Magyarország és Lengyelország képviseltette magát államfői szinten.

\section{Epilógus}

Losonczi egyik utolsó külföldi látogatása a szovjet fővárosba vezetett, Mihail Gorbacsov főtitkárrá választásához kapcsolódott. 1985. március 13-án háromtagú magyar delegáció képviselte Magyarországot Moszkvában, Konsztantyin Csernyenko temetésén. Az esemény egyúttal az új szovjet vezetővel való kapcsolatfelvételre is alkalmat adott.

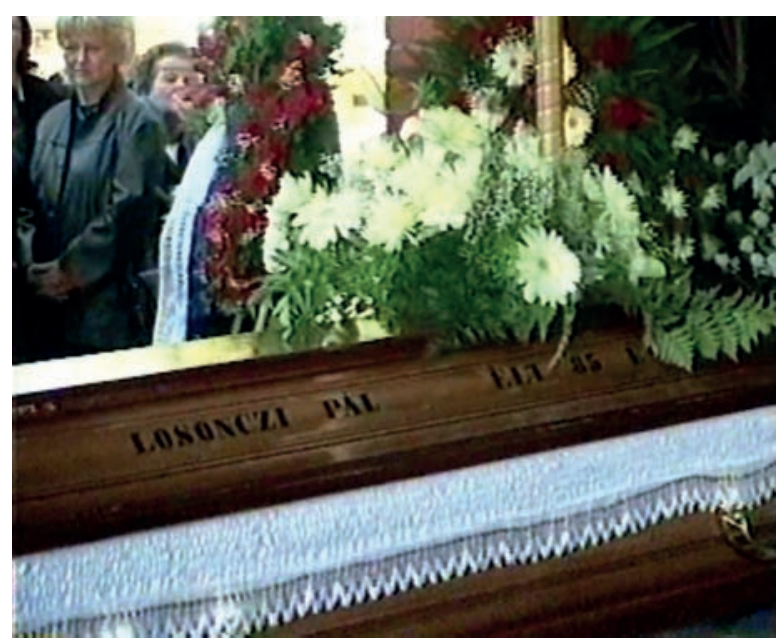

Losonczi Pál temetése, Barcs, 2005.

(Rippl-Rónai Múzeum Újkortörténeti gyüjtemény)

39 A veszélyeket csak nemzetközi összefogással lehet elhárítani.= Losonczi Pál: Erősödő népi-nemzeti egység, békés egymás mellett élés. Válogatott beszédek, cikkek 1960-1984. Bp., Kossuth, 1984. 301-304. p.

40 Tárgyalt számos elnökkel (finn, iraki, jugoszláv, koreai, lengyel, nicaraguai, portugál elnökkel, ill. alelnökkel, az indiai, kínai, luxemburgi, nyugatnémet, osztrák, suriname-i, török, zimbabwei) és több külügyminiszterrel. Bolvári-Takács Gábor: Csendben a csúcson. Vázlatpontok Losonczi Pál államfői portréjához. Zempléni Múzsa. VIII. évfolyam 3. (31.) szám - 2008. ősz, 21. p 
Államfőként Losonczi Pál egyetlen hazai kitüntetést kapott, a Magyar Népköztársaság Érdemrendjét, ${ }^{41} 1979$ ben, 60. születésnapja alkalmából. 65 . születésnapjára pedig megjelent (egyetlen) beszédgyűjteménye.

Losonczi, addig maradt a helyén, amíg Kádár szükségesnek látta. Nyugdíjazása ugyancsak egy átfogó káderpolitikai átrendeződés során történt meg. Az MSZMP KB június 23-i ülésén visszahívták a Politikai Bizottságból. Ezt követően pedig az országgyűlés 1987. június 2526-i zárt ülésén, nyugdíjba vonulása miatt, visszahívták a NET elnöki posztjáról, de továbbra is a testület tagja maradt. A politikától való teljes visszavonulására 1989 februárjában került sor. Levélben jelentette be, hogy lemond KB-tagságáról, képviselői mandátumáról, Elnöki Tanácsi tagságáról, amit a KB elfogadott. Március 8-án képviselői lemondását az országgyülés is elfogadta. Formaság volt már csupán, s ezzel jelképesen egy politikai korszak is lezárult.

Losonczi Pál másfél évtizeddel élte túl a rendszerváltást. Életútja jól szemlélteti a kádári Magyarország vezetői kiválasztódásának mechanizmusát. Személye az egykori pártelit legrejtőzködőbb tagjai közé tartozik. Ránk hagyományozott kitüntetéseinek sokasága azonban megannyi tájékozódási pont lehet életmúvének, illetve a Kádár-kori Magyarország külpolitikájának kutatásában.

\title{
Merit and Protocol. Head of States' Medals in the Rippl-Rónai Museum
}

\author{
ÉVA VARGA
}

\begin{abstract}
„He really did not like the protocol and God punished him with protocol became his field of work" - it was told about Pál Losonczi by István Kapossi Kiss, who was the secretery of press and the speechwriter of the Presdential Counsil's president. His personality belongs one of the most hiding members of the former elit of the party.
\end{abstract}

The former head of state's path is a good exmaple to demonstrate the leader selection's mechanism in Kadar's Hungary. We are writing about him now in the case of his medals, which are owned by the Somogy County Museum and which are being processed to present us, who Pál Losonczi really was.

It is a particular story, how the collection got into the museum's ownership. The story began in 198788 , when an exhibition was created in the Museum of Kaposvár. In this time the exhibition was extraordinary from many point of wiev. On the one hand these medals are the most beautiful pieces of the Phaleristics. At that time Pál Losonczi's medal-collection was the largest of the order of the Hungarian stateman's medal-collections after 1918. On the other hand „there was no example of any medals, orders, ornaments, which were given after important public service, became the treasure of the public" - written by the reporter of the local daily paper in 1988. István Gyenesei, who was the presindent of the Counsil of Somogy County that time, said that „Pál Losonczi's gesture was an example".

The exhibition attracted the visitors. It lived change of the regime and survived it a few years. It had to be teared down and return to the former head of state in 1991. After it the objects' thirteen-year period of incubation was begun. Museums and private collectors also aspired to acquire it, untill the collection of Losonczi - the medal-collection without the souvenirs - returned to the Somogy County Museum.
The experts have no difficulty with Losonczi's native medals. The first, rural period of his career, when came into the national policy's attention could be discribed by the help of the literature.

He was a sucsessfull agricultoral co-chairman and he became the Minister of Agriculture in 1960. Seven years after untill 1987, he was the head of state as the president of the Presidential Council of the Hungarian People's Republic. As „a pure invention of Kádár” Losonczi was not an independent power-political factor, internal policy manegement was outside of his authority and personal possibilities. His work as a statesman was mostly restricted in foreign relations' managemant and paticipation. His sweep, which was framed by the oneparty state, could be described with his abroad trips.

According to the diplomatic protocol he received high levels of external awards, during his abroad visitations and receptions of foreign political dignitaries as the president of the Presidential Council of the Hungarian People's Republic.

High level, leading foreig medals, coins, which are regarded to the collection of the Somogy County Museum, eighth part is origined from West-Europe (Finland, Austria, Spain, Portugal, Ciprus), fith part is from the former Sovjetunion, nearly third part of it from friend socialist states (Czechoslovakia, Poland, Bulgaria, Democratic Republic of Vietnam, Democratic Republik of Korea, Mongolia, Cuba) and approximately the half of it from so-called developing (African, Latin-American, Asian) countries.

If we examine medals as historical sources, the details of the native diplomacy are revealed. The first medal in cronologial order was the Finnish one, which is a good example for the presentation.

Pál Losonczi survived the change of the regime with a decade and a half. The crowd of his medals, which he left for us could be inform us to quest his oeuvre. 


\section{Finn Fehér Rózsa Érdemrend nagykeresztje a láncon (1969. október 1.)}

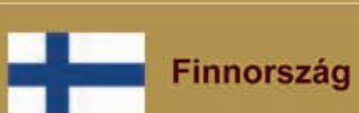

A Fehér Rózsa Érdemrendet 1919. január 28-án báró Carl Gustaf Mannerheim régens alapitotta, majd módositotta 1919. május 16-án. A jelenleg érvényben levö rendelet 1940. június 1-jétöl datálódik. Azóta is folyamatosan adományozzák. December 6-a, Finnország függetlenségének napja az érdemrend ceremónia napja.

Általános érdemrend. Az érdemrend adományozásával külföldiek és finn állampolgárok Finnországért tett szolgálatait ismerik el (továbbá háborús idökben a küzdelemben tanúsított bátorságot). ${ }^{2}$

$\mathrm{Az}$ érdemrend adományozásával egy itélötábla foglalkozik, amely a kancellárból, a kancellár helyetteséböl és legalább négy más tagból áll. Az rend nagymestere a finn elnök.

A rend vállszalagja (és szalagjai): egyszinű sőtétkék selyem.

Az érdemrendnek öt fokozata van: a nagykereszt, a parancsnoki első osztály, a parancsnoki, a lovagi első osztály és a lovagi.

Losonczi Pál hivatalosan két alkalommal (1969-ben, 1976-ban) fogadta Kekkonen elnököt, 1982-ben pedig Mauno Koivisto elnököt Magyarországon. Az elnöki tanács elnöke az 1969-es finn látogatás viszonzására - felesége kiséretében - 1971-ben utazott Finnországba. (Itt jegyezzük meg, hogy a Somogyi Néplap akkori föszerkesztöje, Jávori Béla is a küldöttséggel utazott, a sajtódelegáció tagja volt. A lap Losonczi külföldi látogatásairól részletesen beszámolt.) A finn államfö 1969-es látogatásának emléke az akkor kapott Fehér Rózsa Érdemrend nagykeresztje láncos, államföknek adományozott változata. A magyar küldöttség 1971-es finnországi utazásakor kaphatta a nagykereszt fokozatot. ${ }^{3}$ Feleségének ugyanekkor a a Finn Fehér Rózsa Jelet adományozták.

\section{Adományozta}

dr.Urho Kaleva Kekkonen, ${ }^{4}$ a Finn Köztársaság elnöke

A rend jelvénye

Arany szegélyü, fehér zománcozású György-kereszt, a kereszt szárai között kardot tartó finn oroszlánokkal. Arany szegélyü, kék középmedalionban arany heraldikai rózsa.

\section{Szinei}

kék, fehér

Érem (medál)

a láncon lógó fehér, zománcozott György-kereszt, melynek ágai között a finn oroszlán (koronás, kivont karddal) látható. A kereszt közepén, kék zománcozott medalionon fehér rózsa.

Méret: kereszt sz.: $5,4 \mathrm{~cm}, m .: 5,9 \mathrm{~cm}$ akasztó $h .: 1,7, \mathrm{~cm}$ lánc $h .: 85,5 \mathrm{~cm}$ Súly: lánc+kereszt: $304 \mathrm{~g}$

Anyag: aranyozott ezüst; diszités: kék, fehér zománc

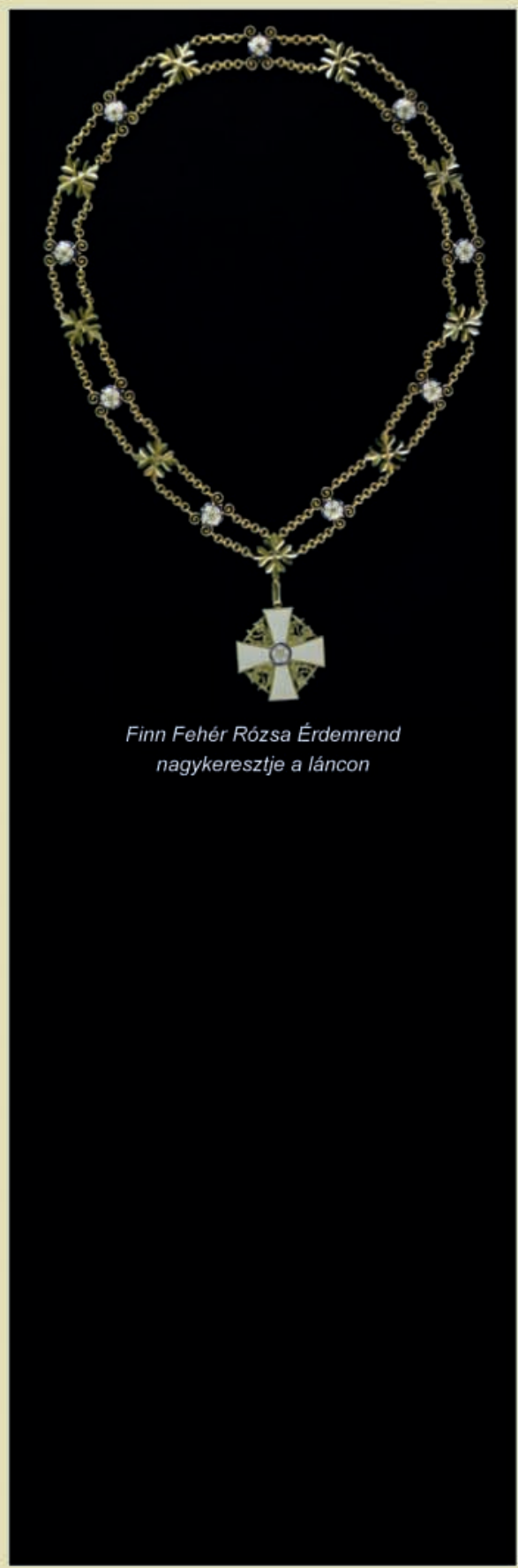




\section{Lánc}

aranyból készült és 9 fehér rózsából (amelyek Finnország 9 megyéjét szimbolizálják) és 9 fenyöágból áll. Az egyes elemek - egy-rózsa, egy fenyőág váltakozva - dupla soros láncszemekkel alkotják a rendi láncot. A medál a középső taghoz - 45 fokban elforgatott fenyőághoz - függesztőszemmel kapcsolódik.

Méret: $h .: 85,5 \mathrm{~cm}$

Anyag: aranyozott ezüst, kék-fehér zománc Súly: lánc a kereszttel $304 \mathrm{~g}$

\section{Vállszalag}

nincs

\section{Csillag}

Ótágú hornyolt ezüst csillag, a csillag sugarai kőzött rövidebb aranyozott sugárnyalábokkal. Középen a jellegzetes fehér rózsa a világoskék medalionban. A rózsa körül futó fekete körgyürüben aranybetũs felirat: ISÄNMAAN HYVÄKSI (A haza szolgálatáért)

Méret: d: $8,4 \mathrm{~cm}$, kitüzö $h .: 6,6 \mathrm{~cm}$,

Súly: $80 \mathrm{~g}$

Anyaga: arany és ezüst;

Diszités: kék, fehér zománc

\section{Miniatür}

nincs

\section{Rozetta}

nincs

\section{Doboz}

Kék mũbőr boritású, teniszütő tokra emlékeztető formájú, tetején arany szinnel a kitüntetés nevét adó fehér rózsa. 5 fém kapoccsal záródik, a doboz fedele leemelhetö. $A$ bélés a doboz fedelében fehér selyem, alul fekete plüss. A fedél belsejében a készitö ékszerész neve A. Tillander olvasható.

Méret: $h: 49 \mathrm{~cm}, s z .: 32 \mathrm{~cm}, m: 4,5 \mathrm{~cm}$

\section{Okiratok}

\section{Adományozó okirat}

1969. szeptember 20-i keltezésũ, finn nyelvũ

Méret: $22 \mathrm{~cm} \times 37,4 \mathrm{~cm}$

\section{Viselési engedély}

Barna mübör kötésũ igazolvány. Budapest, 1970. január 12-i keltezéssel. (megj.: az engedélyen a „Finn Fehér Rózsa Érdemrend nagykeresztje a láncokkal" elnevezés szerepel. Az adományozásról a Magyar Közlöny 1970. január 22. számában olvashatunk.)
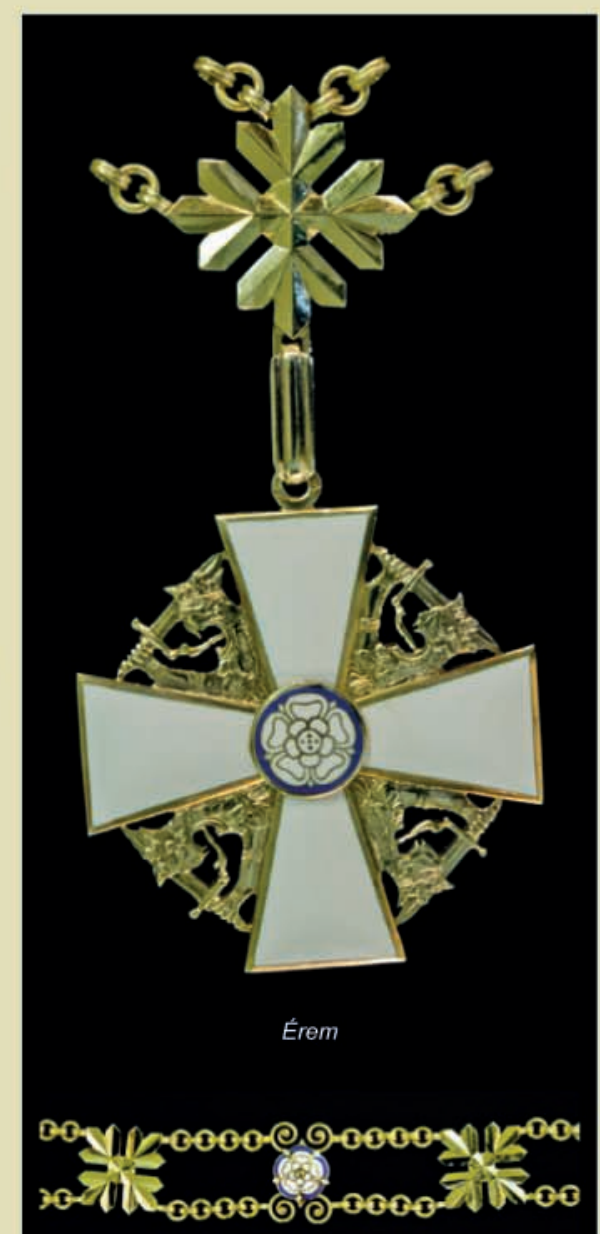

Lánc (részlet)

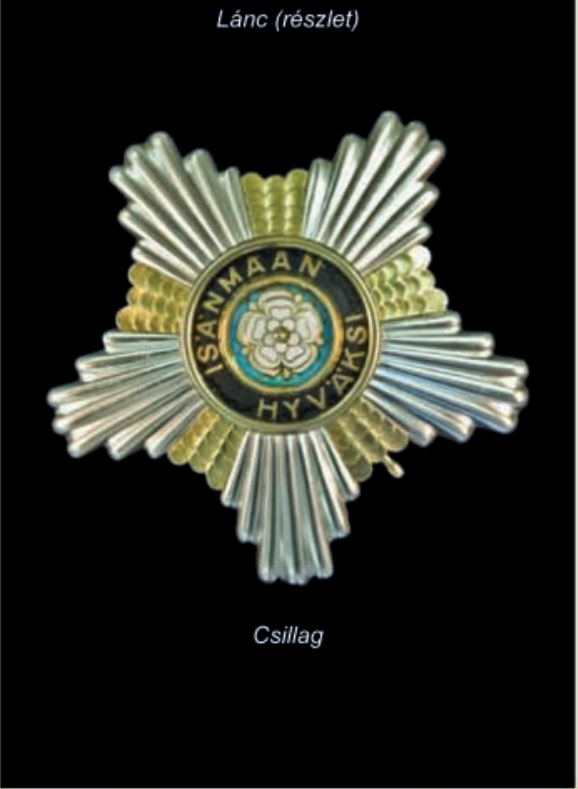


Méret: $6,9 \times 9,1 \mathrm{~cm}$ (becsukva)

\section{Anyag}

aranyozott ezüst, ezüst, zománc

\section{Technika}

préselés, zománcozás

\section{Készitő}

A. Tillander, finn állami ékszerész

\section{Kik kapták}

II. Erzsébet angol királynő (1961)

Charles de Gaulle (1962)

Josip Broz Tito (1963)

Kádár János (1969. szeptember 29.)

Leonyid Iljics Brezsnyev (1976)

Haile Selassie (én.)

I. János Károly spanyol király (én.)

II. Margit dán királynő (én.)

\section{Becsült érték}

\section{Irodalom}

Magyar Közlöny. 1970. január 22.

Népszabadság. 1969. október 2.

Somogyi Néplap. 1969. szeptember 27.- október 3.

Makai Ágnes-Héri Vera: Bp., 2002. 254. p.

Urho Kekkonen

Urho Kekkonen (angol)

Finn Fehér Rózsa Érdemrend (angol)

Finn Fehér Rózsa Érdemrend (angol)

Finn Fehér Rózsa Érdemrend (finn)

Bolvári-Takács Gábor: Eszme és föld. Vázlatpontok Losonczi Pál agrárpolitikusi portréjához.= Zempléni Múzsa. 2006. 2. sz. 11-24. p.

Bolvári-Takács Gábor: Csendben a csúcson. Vázlatpontok Losonczi Pál államföi portréjához. Zempléni Múzsa.VIII. évfolyam 3. (31.)szám 2008. ösz.

Rokoni körben. A magyarországi finn képviselet története. Szerk.: Jakoo Sivers. Bp., 2010. a Finn Nagykövetség kiad.

\footnotetext{
${ }^{1}$ Az adományozási okiraton elốbbi dátum, 1969, szeptember 20, szerepel.

${ }^{2}$ Finn rokonaink története itthon kevèssé ismert, noha a finn-magyar baráti kapcsolatok a két állam kapcsolatának hivatalos szintre emelkedésénél jóval korábbra nyưlnak vissza. Arra az időszakra, amikor mindkét nemzet a tudomány, a mũvészet és az irodalom eszközével alapozta meg önállóságát. A független finn állam közel 700 éves svéd, illetve 1809-ben kezdödö orosz fennhatóság éveit követöen, nem sokkal a bolsevik forradalom után, 1917 december 6-án jött létre. Magyarország pedig a trianoni békekotéssel nyerte el onállóságát. A magyar képviselet már 1928 óta mükőobtt Finnországban Finnország pedig 1934-ben nyitotta meg magyarországi követségét.

Az 1918-as finn polgárháború évekre meghatározta az ország politikai irányvonalát. Finnország az orosz fennhatóság után német érdekszférába került.
} 
A II. világháború idején Finnország kétszer is harcolt a Szovjetunió ellen. Először az 1939-1940-es téli háborúban (segítséget kapott többek között Svédországtól, illetve egy zászlóaljnyi ơnkẻntest Magyarországtól is), majd 1941 és 1944 között (Németország jelentékeny segitségével). Ezt követte a Lappföldi háború 1944 . 1945-ben, amikor Finnország kivonulásra kényszeritette a németeket az országból.

A II. világháborủ következtében Finnország jelentős terūleteket vesztett. Ezek egy részén szervezték meg a szovjet Karéliảt, más részét a leningrádi, illetve a murmanszki terūlethez csatolták.

A II. világháború után Finnország a Szovjetunió ès a nyugati országok között ưtközözóna. Társadalmi berendezkedése nyugati mintát követett, katonailag azonban kiszolgáltatott volt a Szovjetuniónak. A Szovjetunió összeomlása után Finnország is ônállóan választhatta meg fejlödésének útját. 1995-ben csatlakozott az Európai Unióhoz, 2002-ben pedig az elsók között tért át az euro használatára.

31976 ill. 1982 (Ez utóbbi dátum szerepel Komisszár Dénes: Mezögazdaság és protokoll. Losonczi Pál kitüntetései a sajtó tükrében cimû tanulmányában (Somogyi Múzeumok Közleményei, Kaposvár, 2007. 103. p.) azzal a megjegyzéssel, hogy valószinûleg Mauno Henrik Koivisto finn elnők 1982-es, hivatalos magyarországi látogatásakor kapta meg a kituntetést Losonczi Pàl.

${ }^{4}$ dr. Urho Kaleva Kekkonen (1900 - 1986) finn politikus, miniszterelnök, kōztársasági elnök.

A Helsinki Egyetemen magánjogot tanult, 1928-ban szerzett diplomát, 1936-ban doktori fokozatot. Az 1920-as évektốl mint jogász egyre szorosabb kapcsolatba került azt agrármozgalommal, 1927-32 között a Mezögazdasági Minisztérium tisztviselöje, 1936-56 közt az Agrárpárt (késöbbi nevén Centrumpárt) parlamenti képviselöje volt. Kezdetben határozott szovjetellenes álláspontot kèpviselt (1940-ben másodmagával ellenezte, hogy bármely finn területet átengedjenek a Szovjetuniónak). 1943-ban azonban felismerte, hogy Németország el fogja vesziteni a háborút, s arra a következtetésre jutott, hogy Finnországnak a baráti semlegesség politikảját kell folytatnia a Szovjetunióval, ha meg akarja örizni függetlenségét.

1936-tól kezdve többször miniszter, majd 1950-56-ban miniszterelnök volt. Paasikivi elnơk halảla után 1956-1981 között ö volt Finnorszàg államföje. A Szovjetunió irányában folytatott óvatos, de baráti politikát a Paasikivi-Kekkonen irányvonalnak nevezték el.

Kekkonen a skandináv államok semlegessègét hirdető politikájával nagy tekintélyt szerzett. 1962-ben és 1968-ban is megválasztották, 1973-ban pedig a parlament 4 évvel meghosszabbitotta harmadik hivatali ciklusát. 1978-ban újból ô lett az államfō, e tisztségröl - megromlott egészsége miatt - 1981-ben mondott le. Neve összeforrt a békés egymás mellett élès és a népek közötti bizalom megteremtéséért folytatott kūzdelem politikájával. E tevékenységének betetözése volt 1975-ben az elsō európai biztonsági és együttmúkődési konferencia megszervezése Helsinkiben.

Érdekességként jegyezzūk meg továbbá:

Diákévei alatt Kekkonen aktiv sportoló volt. 1924-ben finn országos bajnok lett magasugrásban, később a finn sportszövetség, majd a finn olimpiai bizottság elnôke. Sportolókẻnt 1929-ben jảrt Magyarországon. 1963-ban nem hivatalos látogatásra érkezett. 1969-es államföi lảtogatása utản 1975-ben Jugoszláviába jơvet-menet tett látogatást Kádár Jánosnál és Losonczi Pálnál. 1976. november 17-20. ismét Magyarországon járt. Egy 2004. évi televiziós mûsor nézöi az egyik legnagyobb finn személyiségnek nyilvánitották. 